\title{
Investigation of global particulate nitrate from the AeroCom phase III experiment
}

\author{
Huisheng Bian ${ }^{1,2}$, Mian Chin ${ }^{2}$, Didier A. Hauglustaine ${ }^{3}$, Michael Schulz ${ }^{4}$, Gunnar Myhre $^{5}$, Susanne E. Bauer ${ }^{6,7}$, \\ Marianne T. Lund ${ }^{5}$, Vlassis A. Karydis ${ }^{8}$, Tom L. Kucsera ${ }^{9}$, Xiaohua Pan ${ }^{10}$, Andrea Pozzer ${ }^{8}$, Ragnhild B. Skeie ${ }^{5}$, \\ Stephen D. Steenrod ${ }^{9}$, Kengo Sudo ${ }^{11,12}$, Kostas Tsigaridis ${ }^{6,7}$, Alexandra P. Tsimpidi ${ }^{8}$, and Svetlana G. Tsyro ${ }^{4}$ \\ ${ }^{1}$ Joint Center for Environmental Technology UMBC, Baltimore, MD, USA \\ ${ }^{2}$ Laboratory for Atmospheres, NASA Goddard Space Flight Center, Greenbelt, MD, USA \\ ${ }^{3}$ Laboratoire des Sciences du Climat et de l'Environnement (LSCE), UMR8212, CEA-CNRS-UVSQ, Gif-sur-Yvette, France \\ ${ }^{4}$ Research and Development Department, Norwegian Meteorological Institute, Oslo, Norway \\ ${ }^{5}$ Center for International Climate and Environmental Research - Oslo (CICERO), Oslo, Norway \\ ${ }^{6}$ NASA Goddard Institute for Space Studies, New York, NY, 10025, USA \\ ${ }^{7}$ Center for Climate System Research, Columbia University, New York, NY, 10025, USA \\ ${ }^{8}$ Department of Atmospheric Chemistry, Max Planck Institute for Chemistry, Mainz, Germany \\ ${ }^{9}$ Universities Space Research Association, GESTAR, Columbia, MD, USA \\ ${ }^{10}$ School of Computer, Mathematical and Natural Sciences, Morgan State University, Baltimore, MD, USA \\ ${ }^{11}$ Graduate School of Environmental Studies, Nagoya University, Nagoya, Japan \\ ${ }^{12}$ Japan Agency for Marine-Earth Science and Technology (JAMSTEC), Yokohama, Japan
}

Correspondence to: Huisheng Bian (huisheng.bian@ nasa.gov)

Received: 20 April 2017 - Discussion started: 9 May 2017

Revised: 22 August 2017 - Accepted: 19 September 2017 - Published: 3 November 2017

\begin{abstract}
An assessment of global particulate nitrate and ammonium aerosol based on simulations from nine models participating in the Aerosol Comparisons between $\mathrm{Ob}$ servations and Models (AeroCom) phase III study is presented. A budget analysis was conducted to understand the typical magnitude, distribution, and diversity of the aerosols and their precursors among the models. To gain confidence regarding model performance, the model results were evaluated with various observations globally, including ground station measurements over North America, Europe, and east Asia for tracer concentrations and dry and wet depositions, as well as with aircraft measurements in the Northern Hemisphere mid-to-high latitudes for tracer vertical distributions. Given the unique chemical and physical features of the nitrate occurrence, we further investigated the similarity and differentiation among the models by examining (1) the $\mathrm{pH}$ dependent $\mathrm{NH}_{3}$ wet deposition; (2) the nitrate formation via heterogeneous chemistry on the surface of dust and sea salt particles or thermodynamic equilibrium calculation including dust and sea salt ions; and (3) the nitrate coarse-mode
\end{abstract}

fraction (i.e., coarse/total). It is found that $\mathrm{HNO}_{3}$, which is simulated explicitly based on full $\mathrm{O}_{3}-\mathrm{HO}_{x}-\mathrm{NO}_{x}$-aerosol chemistry by all models, differs by up to a factor of 9 among the models in its global tropospheric burden. This partially contributes to a large difference in $\mathrm{NO}_{3}^{-}$, whose atmospheric burden differs by up to a factor of 13 . The atmospheric burdens of $\mathrm{NH}_{3}$ and $\mathrm{NH}_{4}^{+}$differ by 17 and 4, respectively. Analyses at the process level show that the large diversity in atmospheric burdens of $\mathrm{NO}_{3}^{-}, \mathrm{NH}_{3}$, and $\mathrm{NH}_{4}^{+}$is also related to deposition processes. Wet deposition seems to be the dominant process in determining the diversity in $\mathrm{NH}_{3}$ and $\mathrm{NH}_{4}^{+}$ lifetimes. It is critical to correctly account for contributions of heterogeneous chemical production of nitrate on dust and sea salt, because this process overwhelmingly controls atmospheric nitrate production (typically $>80 \%$ ) and determines the coarse- and fine-mode distribution of nitrate aerosol. 


\section{Introduction}

Atmospheric aerosols adversely affect human health and play an important role in changing the Earth's climate. A series of multi-model studies has been coordinated by the international activity of Aerosol Comparisons between Observations and Models (AeroCom) in its phase I and II model experiments that have systematically assessed the presence and influence of almost all major atmospheric anthropogenic and natural aerosols (such as sulfate, dust, and carbonaceous aerosols) (e.g., Kinne et al., 2006; Schulz et al., 2006; Textor et al., 2006; Koch et al., 2009; Huneeus et al., 2011; Tsigaridis et al., 2014; Kim et al., 2014). Very little attention has been drawn to nitrate aerosol (hereafter "nitrate", referring to particulate nitrate unless otherwise specified) other than its contribution to radiative forcing (Myhre et al., 2013). One obvious reason is that not many models used to include nitrate due to the chemical complexity of nitrate formation. However, atmospheric nitrate aerosol not only exerts direct effects on air quality and climate but also uniquely impacts the Earth system by being directly involved in tropospheric chemistry and constraining net primary productivity, hence altering carbon sequestration and ecological effects via its deposition (Prentice et al., 2001).

Atmospheric nitrate contributes notably to total aerosol mass in the present day, especially in urban areas and agriculture regions. Nitrate is about a quarter of sulfate in terms of overall global burden, aerosol optical depth (AOD), and direct forcing at the present day according to the AeroCom phase II direct forcing experiment (Myhre et al., 2013). This conclusion is confirmed by recent publications using various individual models and emission inventories (Bellouin et al; 2011; Bauer et al., 2007; Hauglustaine et al., 2014; Karydis et al., 2016; Mezuman et al., 2016; Paulot et al., 2016). Regionally, considerable evidence from in situ measurements (Bessagnet and Rouil, 2014; Haywood et al., 2008; Jimenez et al., 2009; Malm et al., 2004; Vieno et al., 2016) and model results (Karydis et al., 2011; Ensberg et al., 2013; Trump et al., 2015) indicates that nitrate becomes one of the major aerosol species in urban and agriculture environments. For example, nitrate concentration is about half of sulfate during the summer season in Beijing (Zhou et al., 2016) and represents a large portion of wintertime aerosol mass in the San Joaquin Valley in California (Pusede et al., 2016).

More importantly, the relative importance of aerosol nitrate is likely to increase over the next century with a projected decline in $\mathrm{SO}_{2}$ and $\mathrm{NO}_{x}$ emissions and increase in $\mathrm{NH}_{3}$ emissions (IPCC, 2013). With the reduction of $\mathrm{SO}_{2}$ emissions, less atmospheric $\mathrm{NH}_{3}$ is required to neutralize the strong acid $\mathrm{H}_{2} \mathrm{SO}_{4}$. The excess of $\mathrm{NH}_{3}$ results in gaseous $\mathrm{HNO}_{3}$ and $\mathrm{NH}_{3}$ entering the condensed phase, and their subsequent dissociation yields nitrate and ammonium ions. The trend of future nitrate depends on whether $\mathrm{NO}_{x}$ or $\mathrm{NH}_{3}$ are the limited species for nitrate formation (Tsimpidi et al., 2007, 2008). Generally, our atmosphere, at its current and foreseeable near future, is still in an $\mathrm{NH}_{3}$-limited condition according to sensitivity studies by Heald et al. (2012) and Walker et al. (2012). Almost all global models predicted an overall increase of atmospheric nitrate burden during this century based on current available emission inventories (Bauer et al., 2007, 2016; Bellouin et al., 2011; Hauglustaine et al., 2014; Li et al., 2014). For example, using CMIP5 future emission projections, Bellouin et al. (2011) concluded that, by 2090, nitrate would become an important aerosol species in Europe and Asia, contributing up to two-thirds of the globally averaged anthropogenic optical depth. However, the predicted trend of surface nitrate is mixed. Some studies estimated a consistent increase of surface nitrate (Bellouin et al., 2011), while others pointed out that this increase might vanish or even reverse over some regional urban areas due to the decline of $\mathrm{NO}_{x}$ emissions (Bauer et al., 2016; Pusede et al., 2016; Trail et al., 2014). Nevertheless, the potentially increasing importance of nitrate in climate and its large uncertainty in future surface nitrate predictions urge us to characterize model performance and understand the physicochemical mechanisms behind the diversity of nitrate simulations.

Nitrate is also important in that its formation directly affects tropospheric chemistry. First, the formation of particulate nitrate, through either aqueous phase chemical reaction between $\mathrm{HNO}_{3}$ and $\mathrm{NH}_{3}$ (Metzger et al., 2002; Kim et al., 1993) or heterogeneous reaction of nitrogen species such as $\mathrm{HNO}_{3}, \mathrm{NO}_{3}$, and $\mathrm{N}_{2} \mathrm{O}_{5}$ on the surface of dust and sea salt aerosol particles (Bauer et al., 2004; Bauer and Koch, 2005; Bian and Zender, 2003; Dentener et al., 1996; Liao et al., 2003), converts gas phase nitrogen species into aerosols. Consequently, the global tropospheric $\mathrm{NO}_{x}$ concentration and the rate of conversion of $\mathrm{N}_{2} \mathrm{O}_{5}$ to $\mathrm{HNO}_{3}$ will be reduced (Riemer et al., 2003), which in turn leads to the reduction of atmospheric oxidants. For example, global tropospheric $\mathrm{O}_{3}$ can be reduced by $5 \%$ (Bauer et al., 2007) and tropical Atlantic $\mathrm{OH}$ by $10 \%$ (Bian and Zender, 2003) just through the heterogeneous reactions of nitrogen radicals on dust. Second, the most important removal path for nitrogen from the atmosphere is the formation of $\mathrm{HNO}_{3}$, which is subsequently deposited (Riemer et al., 2003). Since $\mathrm{HNO}_{3}$ is subject to partitioning between the gas and aerosol phases, the lifetimes of nitrogen species can be shortened by the formation of tropospheric nitrate aerosol because the loss of total $\mathrm{HNO}_{3}$ will be accelerated by a much higher dry deposition in the aerosol phase.

Large nitrogen deposition occurs over both land and ocean (Dentener et al., 2006; Kanakidou et al., 2012, 2016). Nitrogen deposition can either benefit or impair ecosystem productivity depending on the initial balance of nutrients since different ecosystems have different $\mathrm{Nr}$ (reactive nitrogen including gas and particulate $\mathrm{NO}_{3}^{-}$and other nitrogen compounds) availability and retention (Galloway et al., 2004; Prentice et al., 2001). If fixed $\mathrm{Nr}$ is deposited as nitrate in forests, it may act as a "fertilizer", stimulating growth and thus enhancing carbon sequestration (Fowler et al., 2015). 
But when the accumulated deposition exceeds the nutritional needs of the ecosystem, nitrogen saturation may result (Fenn et al., 1996). Soil fertility declines due to the leeching of cations (Van Milegroet and Cole, 1984), and thus carbon uptake diminishes. The balance between fertilization and saturation depends on the spatial and temporal extent of nitrogen deposition. In order to determine the extent to which the emissions of air pollutants will have to be reduced and whether the environment needs to be protected from damage, it is essential to know where and by how much $\mathrm{N}$ deposition exceeds nature's tolerance (Dentener et al., 2006; Lamarque et al., 2005; Phoenix et al., 2006).

Here, we present a nitrate-focused study that has been organized as a part of the series of AeroCom phase III experiments (https://wiki.met.no/aerocom/ phase3-experiments). The goals of this activity are to (1) address the diversity of the nitrate simulation by the AeroCom multi-models and diagnose the driving processes for the diversity, (2) explore the uncertainty of the model nitrate simulations constrained against various measurements from ground station networks and aircraft campaigns, and (3) investigate how the formation of nitrate changes in different models in response to perturbation on key precursors and factors that determine nitrate formation. We focus on the first two objectives in this paper. Such a study directs us on how to improve the representation of nitrate aerosol formation and size distribution in climate chemistry models and reveals nitrate effects on global air quality and climate.

Building upon the analysis of the multi-model diversity, three additional sensitivity experiments are designed using the Global Modeling Initiative (GMI) model to further explore the potential sources for the diversity on physical and chemical process levels. First, we explore the impact of $\mathrm{pH}$ dependent $\mathrm{NH}_{3}$ wet deposition on atmospheric $\mathrm{NH}_{3}$ and associated nitrogen species. We then reveal the importance of mineral dust and sea salt in the nitrate formation and check the resultant nitrate aerosol size distribution that is particularly important in nitrate forcing estimation.

The paper is organized as follows. Section 2 introduces the experiment setup including the emission inventories used and the participating AeroCom models. Observations of surface tracer concentrations and dry and wet depositions over the US, Europe, and east Asia, as well as aircraft measurements in the ARCTAS campaigns, are described in Sect. 3. We present AeroCom model intercomparison and the model evaluation using aforementioned observations in Sect. 4. Based on the knowledge from previous sections, we further discuss nitrate formation in response to physiochemical methodologies in Sect. 5 and summarize our major findings in Sect. 6.

\section{Experiment setup and AeroCom model description}

\subsection{Experiment setup}

The AeroCom phase III nitrate experiment comprises one baseline and six perturbation simulations, with the latter designed for assessing the possible future changes of emission and meteorological fields relevant to nitrate formation. Models are advised to use the same prescribed emission datasets for gases and aerosols. Emissions from anthropogenic, aircraft, and ship sources for aerosol and ozone simulations are obtained from the recently developed HTAP v2 database (Janssens-Maenhout et al., 2015) that provides high-spatialresolution monthly emissions. The tracers that are included in ozone chemistry but are not provided by HTAP v2 (i.e., some volatile organic compounds) should be obtained from CMIP5 RCP85 with a linear interpolation between 2005 and 2010. Biomass burning emissions are the emissions of GFED3 (van der Werf et al., 2010) in 2008. The $\mathrm{NH}_{3}$ emission from the ocean is adopted based on the compilation of the GEIA emission inventory (Bouwman et al., 1997). Participating modeling groups use their own emissions of dimenthyl sulfide (DMS), dust, sea salt, and NO from lightning, since they are calculated based on models' meteorological fields.

A full-year simulation for 2008 is required for the nitrate model experiment. There are several in situ observation datasets available in 2008 for model evaluation, including the surface concentration and deposition measurements over the US (CASTNET, AMoN, NDAP NTN), Europe (EMEP), and Asia (EANET), and the aircraft measurements of vertical profiles (e.g., ARCTAS-A, ARCTAS-CARB, and ARCTASB). All participating models are required to use the reanalysis or nudged meteorological data for 2008 and allow a 1-year spin-up for the baseline simulation.

\subsection{AeroCom models}

Nine models participated in the AeroCom phase III nitrate experiment. Their general nitrate-related physiochemical mechanisms are summarized in Table 1. Further detailed information on their thermodynamic equilibrium model (TEQM) is given in Table 2 .

The models participating in this study are divided into two groups. Group one (CHASER, EMAC, INCA, GISSMATRIX, and GISS-OMA) ran chemical fields together with meteorological fields, while group two (EMEP, GMI, OsloCTM2, and OsloCTM3) simulated chemical fields using archived meteorological fields. Most models in this study have a horizontal resolution around $2-3^{\circ}$ (except EMEP with $\left.0.5^{\circ}\right)$. Vertically, most models cover both the troposphere and the stratosphere, with a peak altitude up to $0.01 \mathrm{hPa}$ (except EMEP which extends vertically up to $100 \mathrm{hPa}$ into the troposphere only). 


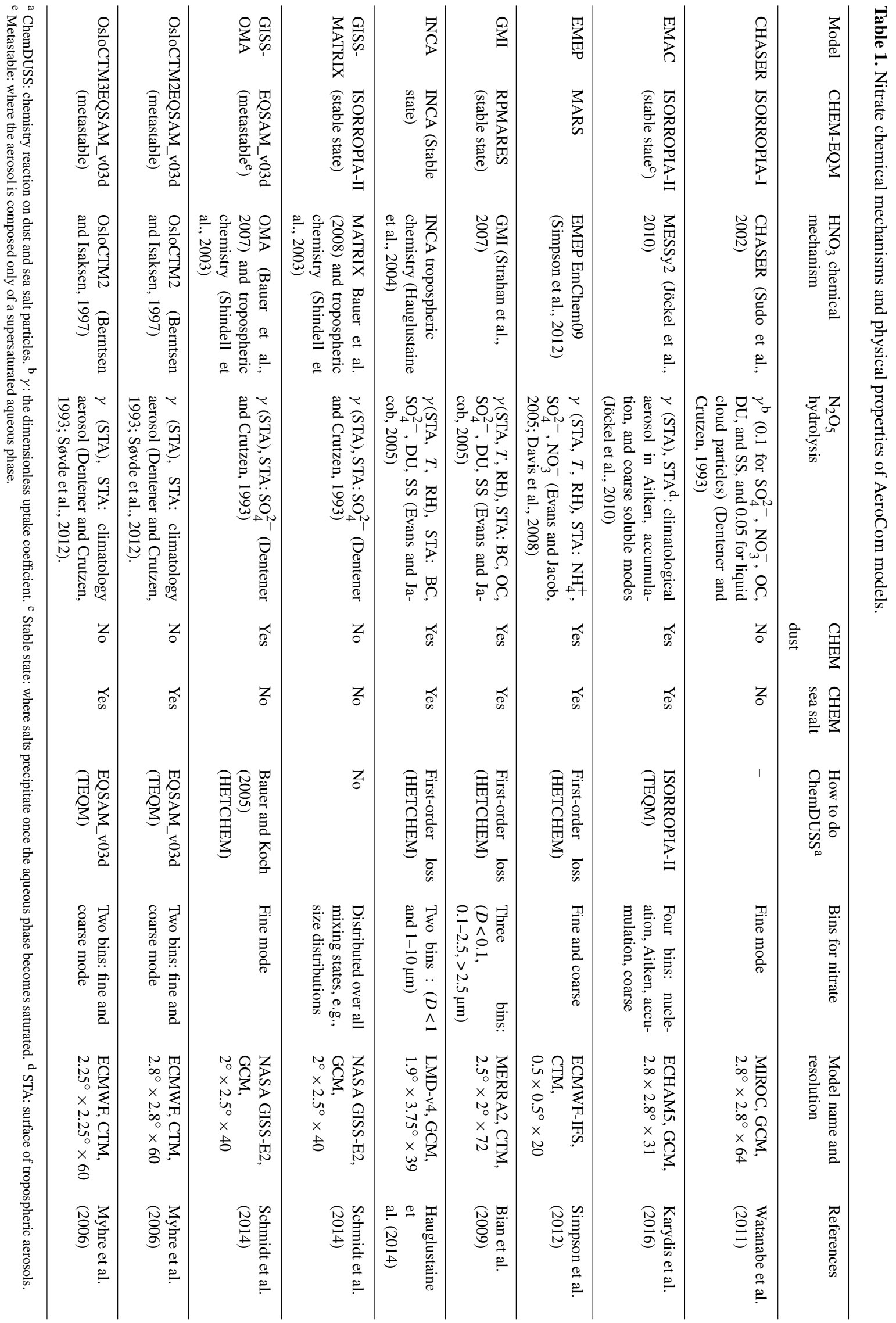


Table 2. Characteristics of thermodynamic equilibrium models.

\begin{tabular}{|c|c|c|c|c|c|c|}
\hline & ISORROPIA-I & ISORROPIA-II & MARS & RPMARES & INCA & EQSAM_v03d \\
\hline Species & $\begin{array}{l}\text { Sulfate, nitrate, } \\
\text { ammonium, } \\
\text { sodium, chloride }\end{array}$ & $\begin{array}{l}\text { Sulfate, nitrate, } \\
\text { ammonium, } \\
\text { sodium, chloride, } \\
\text { crustal species }\end{array}$ & $\begin{array}{l}\text { Sulfate, nitrate, } \\
\text { ammonium }\end{array}$ & $\begin{array}{l}\text { Sulfate, nitrate, } \\
\text { ammonium }\end{array}$ & $\begin{array}{l}\text { Sulfate, nitrate, } \\
\text { ammonium }\end{array}$ & $\begin{array}{l}\text { Sulfate, nitrate, } \\
\text { ammonium, } \\
\text { sodium, chloride }\end{array}$ \\
\hline No. of components & 23 & 34 & 16 & 11 & 9 & 18 \\
\hline No. of reactions & 15 & 27 & 7 & 6 & 4 & 25 \\
\hline $\begin{array}{l}\text { Multi-component } \\
\text { activity coefficient }\end{array}$ & Bromley & Bromley & Bromley & Bromley & $\begin{array}{l}\text { Seinfeld and } \\
\text { Pandis }\end{array}$ & Metzger \\
\hline $\begin{array}{l}\text { Binary activity } \\
\text { coefficient }\end{array}$ & $\begin{array}{l}\text { Kusik and Meiss- } \\
\text { ner }\end{array}$ & $\begin{array}{l}\text { Kusik and Meiss- } \\
\text { ner }\end{array}$ & Pitzer & Pitzer & $\begin{array}{l}\text { Seinfeld and } \\
\text { Pandis }\end{array}$ & Metzger \\
\hline Water activity & $\mathrm{ZSR}^{*}$ & ZSR & ZSR & ZSR & & ZSR \\
\hline Kelvin effect & No & No & No & No & No & No \\
\hline $\begin{array}{l}\text { Quantities that } \\
\text { determine } \\
\text { subdomains }\end{array}$ & $\begin{array}{l}{\left[\mathrm{Na}^{+}\right],\left[\mathrm{NH}_{4}^{+}\right],} \\
{\left[\mathrm{SO}_{4}^{2-}\right]}\end{array}$ & $\begin{array}{l}{\left[\mathrm{Ca}^{2+}\right],\left[\mathrm{K}^{+}\right],} \\
{\left[\mathrm{Mg}^{2+}\right],\left[\mathrm{Na}^{+}\right],} \\
{\left[\mathrm{NH}_{4}^{+}\right],\left[\mathrm{SO}_{4}^{2-}\right]}\end{array}$ & $\begin{array}{l}\mathrm{RH},\left[\mathrm{NH}_{4}^{+}\right], \\
{\left[\mathrm{SO}_{4}^{2-}\right]}\end{array}$ & {$\left[\mathrm{NH}_{4}^{+}\right],\left[\mathrm{SO}_{4}^{2-}\right]$} & {$\left[\mathrm{NH}_{4}^{+}\right],\left[\mathrm{SO}_{4}^{2-}\right]$} & {$\left[\mathrm{NH}_{4}^{+}\right],\left[\mathrm{SO}_{4}^{2-}\right]$} \\
\hline No. of subdomains & 4 & 5 & 4 & 2 & 3 & 3 \\
\hline
\end{tabular}

* ZSR: Zdanovskii-Stokes-Robinson.

All models use full gas phase $\mathrm{O}_{3}-\mathrm{NO}_{x}-\mathrm{HO}_{x}$ chemistry to produce $\mathrm{HNO}_{3}$ and consider the feedback of nitrate aerosol formation on $\mathrm{HNO}_{3}$ calculation (i.e., changes in $\mathrm{HNO}_{3}$ concentrations due to the gas/particle equilibrium). Meanwhile, all models consider $\mathrm{N}_{2} \mathrm{O}_{5}$ hydrolysis, the conversion of $\mathrm{N}_{2} \mathrm{O}_{5}$ to $\mathrm{HNO}_{3}$. The first-order loss reaction occurs on the surface of tropospheric aerosols and assumes irreversible instant reaction. However, the models differ in $\mathrm{N}_{2} \mathrm{O}_{5}$ hydrolysis by considering the reaction on the surface of different aerosol types. Uptake coefficients (also known as gamma factors) also differ in their relationship to temperature and relative humidity ( $\mathrm{RH})$. CHASER model is special, as it allows $\mathrm{N}_{2} \mathrm{O}_{5}$ conversion to $\mathrm{HNO}_{3}$ on liquid cloud particles. Please refer to Table 1 and the listed references for details. Due to the complexity of chemical mechanisms for organic nitrate compounds and different recommendations for reaction rates, $\mathrm{HNO}_{3}$ fields produced by the models differ greatly. This difference propagates into the subsequent gas-aerosol reactions for nitrate formation.

These models are very different in their approaches on gas-aerosol reactions in nitrate formation. All models consider reactions between $\mathrm{NH}_{3}$ and $\mathrm{HNO}_{3}$. However, models differ dramatically in whether they include contributions of dust and sea salt (Table 1). Some account for both, some for only dust or sea salt, and some do not account for any of them at all. The methods used by the models in accounting for $\mathrm{NH}_{3}$ and dust/sea salt contributions are also different. Please also note that the heterogeneous chemical production of particulate nitrate mentioned in this paper refers only to the firstorder loss reaction of $\mathrm{HNO}_{3}$ on the surface of dust and sea salt particles. A series of reactions, such as $\mathrm{N}_{2} \mathrm{O}_{5}$ hydrolysis and $\mathrm{BrONO}_{2}$ hydrolysis, affect $\mathrm{HNO}_{3}$ simulation. These re- actions are typically considered in $\mathrm{O}_{3}-\mathrm{NO}_{x}-\mathrm{HO}_{x}$ chemistry and their discussion is beyond the scope of this paper.

All participating models adopt TEQM to deal with aqueous and solid phase reactions and gas-aerosol partitioning (Tables 1 and 2). This is based on the assumption that volatile species in the gas and aerosol phases are generally in chemical equilibrium. However, the assumption is not always warranted in some cases, as we will discuss in Sect. 5.2. Even with the TEQM approach, nitrate calculation could differ due to treatments of equilibrium constants or chemical potentials, solute activity coefficients, water activity, and relative humidity of deliquescence (RHD). The parameterizations adopted by the models to deal with multi-component activity coefficient, binary activity coefficient, and water activity are given in Table 2. GISS-OMA, OsloCTM2, and OsloCTM3 are special in that they assume aerosols to be metastable so that the model does not take into account formation of solids in this study. All other models do consider the effect of the hysteresis of particle phase transitions. All models also assume that the overall particles are large enough to neglect the Kelvin effect.

The participating models call the TEQMs in different ways to account for aerosol size effect. All the TEQMs (ISORROPIA-I, ISORROPIA-II, MARS, RPMIRES, INCA, and EQSAM3) assume particles to be internally mixed; i.e., all particles of the same size have the same composition. However, some parent models (CHASER, EMEP, GMI, INCA, GISS-MATRIX, and GISS-OMA) call their TEQMs only once for fine-mode aerosol particles, while the others (EMAC, OsloCTM2, and OsloCTM3) call their TEQMs from different aerosol size bins. For example, OsloCTM2 and OsloCTM3 consider a bimodal aerosol size spectrum with two major aerosol modes (fine and coarse) and calculate 
gas-aerosol equilibrium partitioning with EQSAM3 first for fine mode and then for coarse mode. Additionally, to account for kinetic limitations, EMAC calculates the phase partitioning in two stages. In the first stage, the number of the gas phase species that are able to kinetically condense onto the aerosol phase within the model time step is calculated, while in the second stage, the TEQM redistributes the mass between the two phases assuming instant equilibrium (Pringle et al., 2010).

The TEQMs also differ in the chemical components considered. Specifically, the TEQMs in CHASE, EMEP, GISS-MATRIX, GISS-OMA, GMI, and INCA include only species of sulfate, nitrate, ammonium, and their gas, liquid, and solid components. The models OsloCTM2 and OsloCTM3 add $\mathrm{NaCl}$ and $\mathrm{HCl}$, while the model EMAC further expands the species by including dust-related crustal material such as $\mathrm{Ca}^{2+}, \mathrm{K}^{+}$, and $\mathrm{Mg}^{2+}$.

These TEQMs differ in their computational approaches as well. Computational efficiency is a prime consideration for a TEQM that is designed for incorporation into a global air quality and climate study. To speed up the calculation, TEQMs typically divide the system into subdomains based on RH and concentrations of ammonium, sodium, crustal cations, and sulfate. Corresponding approximation could be adopted for each subdomain with the minimum numbers of equilibriums and unknown components. As listed in Table 2, the numbers of subdomains are 4, 5, 4, 2, 3, and 3 for the TEQM ISORROPIA-I, ISORROPIA-II, MARS, RPMIRES, INCA, and EQSAM3, respectively.

The ways to account for the contribution of dust and sea salt to nitrate formation are also different (see Table 1 column "How to do ChemDUSS"). Some models (EMAC, OsloCTM3, and OsloCTM2) include dust and/or sea salt components in their TEQM models directly (marked as TEQM in Table 1 under column "How to do ChemDUSS"), while some models (EMEP, GISS-OMA, GMI, and INCA) use an approach of first-order loss rate outside their TEQMs to account for the heterogeneous reactions of $\mathrm{HNO}_{3}$ on the surface of dust and sea salt (marked as HETCHEM in Table 1). For the latter approach, the gamma rates and their RH dependence adopted by the models differ as well.

Dry and wet deposition of $\mathrm{NH}_{3}$, ammonium nitrate, and ammonium sulfate are treated similarly to other gas and aerosol tracers in the models. It is worth pointing out that there is a different consideration for the Henry's law constant of $\mathrm{NH}_{3}$ used by the models. Some models modify it based on the $\mathrm{pH}$ value of cloud water, while others do not. We will discuss the impact of these two treatments on nitrate simulation in Sect. 5.1.

We introduce only the major characteristics of thermodynamic equilibrium models since this study aims for the evaluation and explanation of overall nitrate diversity among the GCM/CTM models from all potential aspects. The detailed discussion of the models' chemical mechanism of gas phase reactions and the aerosol optical properties adopted by the models is also beyond the scope of this work. Readers could refer to the references listed in Tables 1 and 2 for any further details.

\section{Observations}

We use surface measurements from ground station networks and aircraft campaigns to evaluate modeled surface concentrations, dry and wet depositions, and vertical distributions of nitrate and related species (Table 3).

\subsection{Surface measurements of concentrations and deposition rates}

Ambient concentrations of sulfur and nitrogen species throughout the US and Canada have been measured by the ground station network CASTNET (Clean Air Status and Trends Network) (Fig. 1). The measurements use a threestage filter pack with a controlled flow rate. The measurements of CASTNET do not include $\mathrm{NH}_{3}$. AMoN (Ammonia Monitoring Network), measuring concentrations of ambient $\mathrm{NH}_{3}$, has been deployed at CASTNET sites starting from October 2007 using passive samplers. The corresponding tracers' surface concentration measurements over Europe have been conducted by EMEP (the European Monitoring and Evaluation Programme). The measured sites of all these networks are located in rural areas or sensitive ecosystems, representing a larger region by avoiding influences and contamination from local sources. Surface concentrations over east Asia are inferred from the measurement of dry deposition by EANET (Acid Deposition Monitoring Network in East Asia). This network provides acid deposition from a regional monitoring network including 13 countries in east Asia using standardized monitoring methods and analytical techniques.

CASTNET also provides dry deposition of sulfate and nitrogen species. Direct measurements of dry deposition fluxes $(D)$ are expensive, so $D$ is calculated as the measured pollutant concentration $(C)$ multiplied by the modeled dry deposition velocity $\left(V_{\mathrm{d}}\right) . V_{\mathrm{d}}$ is either estimated by the multi-layer model fed with measured hourly meteorological data or derived from historical average $V_{\mathrm{d}}$ for sites with discontinued meteorological parameters.

Direct measurements of wet deposition fluxes of sulfate, nitrate, and other ions have also been performed by NADP NTN (the National Atmospheric Deposition Program - National Trends Network) across the contiguous US, Canada, Alaska, and the US Virgin Islands and EANET over east Asia. Sites are predominantly located away from urban areas and point sources of pollution. Each site has a precipitation chemistry collector and gauge. Both networks can measure wet deposition for a continuous period (weekly for NADP NTN and daily for EANET) or every precipitation event if using an automated collector (wet-only sampling). 
Table 3. Summary of the observational data used in this study.

\begin{tabular}{|c|c|c|c|c|c|}
\hline $\begin{array}{l}\text { Surface } \\
\text { network }\end{array}$ & Quantity & Cover area & $\begin{array}{r}\text { No. of sites } \\
\text { in } 2008\end{array}$ & $\begin{array}{l}\text { Sample } \\
\text { frequency }\end{array}$ & Source \\
\hline \multirow[t]{2}{*}{ CASTNET } & $\begin{array}{l}\text { Concentration of } \mathrm{HNO}_{3}, \\
\mathrm{NO}_{3}^{-}, \mathrm{NH}_{4}^{+}, \mathrm{SO}_{4}^{2-}\end{array}$ & \multirow[t]{2}{*}{ North America } & \multirow[t]{2}{*}{83} & \multirow[t]{2}{*}{ Weekly } & \multirow[t]{2}{*}{ http://www.epa.gov/castnet/clearsession.do } \\
\hline & Dry deposition of them & & & & \\
\hline AMoN & Concentration of $\mathrm{NH}_{3}$ & US & 19 & 2-weekly & http://nadp.isws.illinois.edu/ \\
\hline NADP NTN & $\begin{array}{l}\text { Wet deposition of } \mathrm{HNO}_{3} \\
+\mathrm{NO}_{3}^{-}, \mathrm{NH}_{4}^{+}, \mathrm{SO}_{4}^{2-}\end{array}$ & US & 253 & Weekly & http://adp.isws.illinois.edu \\
\hline EMEP & $\begin{array}{l}\text { Concentration of } \mathrm{HNO}_{3}, \\
\mathrm{NH}_{3}, \mathrm{NO}_{3}^{-}, \mathrm{NH}_{4}^{+}, \mathrm{SO}_{4}^{2-}\end{array}$ & Europe & 35 & Daily & http://www.nilu.no/projects/ccc/index.html \\
\hline \multirow[t]{2}{*}{ EANET } & $\begin{array}{l}\text { Concentration of } \mathrm{HNO}_{3} \text {, } \\
\mathrm{NH}_{3}, \mathrm{NO}_{3}^{-}, \mathrm{NH}_{4}^{+}, \mathrm{SO}_{4}^{2-}\end{array}$ & \multirow[t]{2}{*}{ East Asia } & \multirow[t]{2}{*}{56} & $\begin{array}{l}\text { Daily to } \\
\text { 2-weekly }\end{array}$ & \multirow[t]{2}{*}{ http://www.eanet.asia/eanet/brief.html } \\
\hline & $\begin{array}{l}\text { Wet deposition of } \mathrm{HNO}_{3} \\
+\mathrm{NO}_{3}^{-}, \mathrm{NH}_{4}^{+}, \mathrm{SO}_{4}^{2-}\end{array}$ & & & $\begin{array}{l}24 \mathrm{~h} \text { or precipi- } \\
\text { tation event }\end{array}$ & \\
\hline $\begin{array}{l}\text { Aircraft } \\
\text { campaigns }\end{array}$ & Quantity & Cover area & $\begin{array}{l}\text { No. of } \\
\text { flights }\end{array}$ & $\begin{array}{l}\text { Campaign } \\
\text { period }\end{array}$ & Source \\
\hline ARCTAS-A & \multirow{3}{*}{$\begin{array}{l}\text { Concentration of } \mathrm{NO}_{3}^{-}, \\
\mathrm{NH}_{4}^{+}, \mathrm{SO}_{4}^{2-}\end{array}$} & Alaska, USA & 11 & March-April & \multirow[t]{3}{*}{ http://www-air.larc.nasa.gov/cgi-bin/arcstat-c } \\
\hline ARCTAS-CARB & & $\begin{array}{l}\text { Bay Area, } \\
\text { California, USA }\end{array}$ & 6 & June & \\
\hline ARCTAS-B & & Central Canada & 7 & July & \\
\hline
\end{tabular}
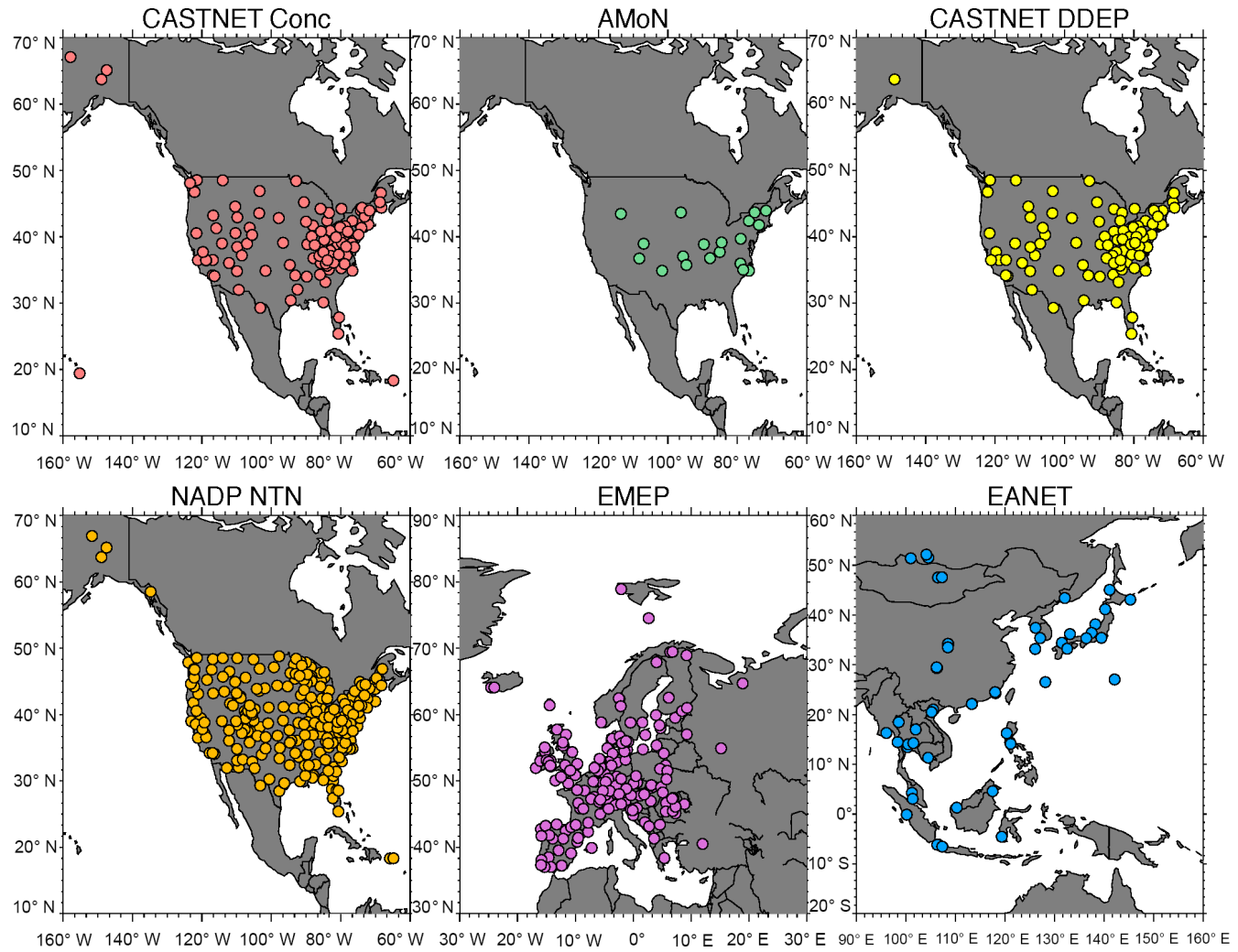

Figure 1. The observational station locations for CASTNET surface concentrations (CASTNET Conc), Ammonia Monitoring Network (AMoN) over the US, CASTNET dry deposition (CASTNET DDep), National Atmospheric Deposition Program - National Trends Network (NADP NTN) for wet deposition over the US, surface concentrations over Europe (EMEP), and surface dry and wet deposition over Asia (EANET). 


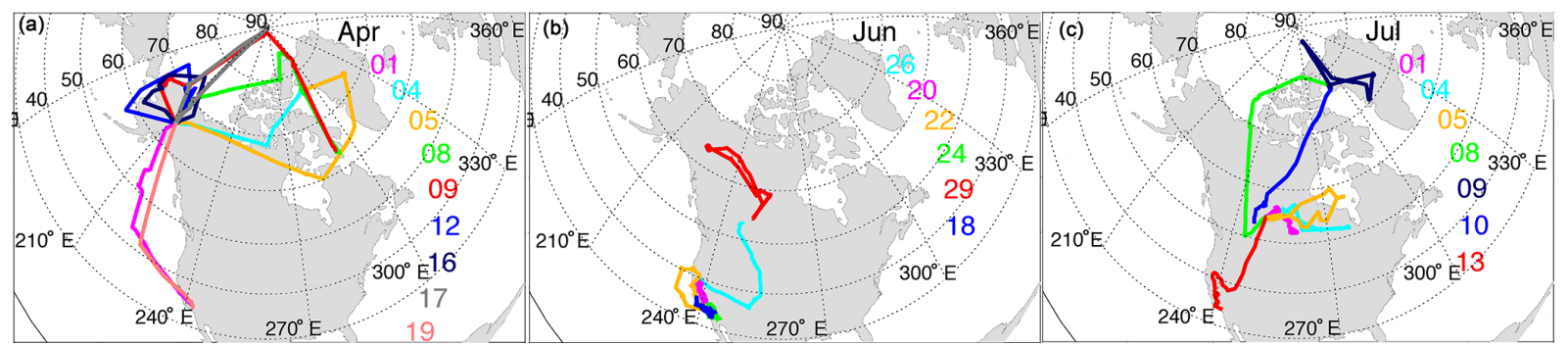

Figure 2. Flight tracks of ARCTAS-A (a), ARCTAS-CARB (b), and ARCTAS-B (c). The colors represent observations during different days.

Data are quality assured for all measurements. Measurements over North America use automated screening techniques, semi-annual calibration results, site operator comments, and manual data review. Quality assurance of EMEP is carried out on both the national level and by the Chemical Co-ordinating Centre (CCC). The quality of EMEP measurements is not equal at the national level (Schaap et al., 2002, 2004). Sites in northern, western, and central Europe were generally well equipped and performing, while sites in the rest of Europe suffered from inadequate sampling and calibrating methods due to political and/or economical reasons. The quality of ammonia measurement is relatively low since some laboratories experienced contamination problems (Williams et al., 1992). Although EANET adopts standardized monitoring methods and analytical techniques, quality assurance is carried out on the national level.

\subsection{Aircraft measurements of vertical profiles}

Aircraft campaign measurements during the 2008 Arctic Research of the Composition of the Troposphere from Aircraft and Satellites (ARCTAS) are used to evaluate tracer vertical distribution simulated by the models (Bian et al., 2013; Jacob et al., 2010). Three phases of the campaign, ranging from Northern Hemisphere midlatitude industrial region (ARCTAS-CARB, June 2008) to high-latitude Arctic regions influenced by long-range pollution transport (ARCTAS-A, April 2008) and by local boreal biomass burning (ARCTASB, July 2008), provide well-encompassing environment observations. All flights were conducted by the NASA DC-8 aircraft and the flight tracks of these three phases are presented in Fig. 2. An onboard high-resolution time-of-flight aerosol mass spectrometer (HR-ToF-AMS) instrument $(\mathrm{Cu}-$ bison et al., 2011; DeCarlo et al., 2006) measured fine-mode aerosol concentrations (PM1) along the flight track including $\mathrm{NO}_{3}^{-}, \mathrm{NH}_{4}^{+}$, and $\mathrm{SO}_{4}^{2-}$ at STP conditions $(1013 \mathrm{mb}$ and $273.15 \mathrm{~K}$ ) at a sampling time interval of $\sim 12 \mathrm{~s}$. An accuracy estimate of 2 standard deviations, likely conservative, is $34 \%$ for inorganics, dominated by the uncertainty in particle collection efficiency due to particle bouncing (Huffman et al., 2005).

\section{Model intercomparison and evaluation}

\subsection{AeroCom model intercomparisons of global distributions and budgets}

\subsection{1 $\mathrm{NH}_{3}$ and $\mathrm{NH}_{4}^{+}$}

Six models use HTAP2 anthropogenic emissions, two (GISSMATRIX and GISS-OMA) use CMIP5 emissions, and one (INCA) uses ECLIPSE emissions. Table $4 \mathrm{~b}$ shows that eight models have the annual $\mathrm{NH}_{3}$ emission values within $5 \%$ of the value from the AeroCom experiment recommended emission inventories, but INCA is $11 \%$ higher. The similar emission distributions ensure that the examined intermodel diversities are truly caused by the differences in physicochemical processes among the models. The normalized root mean square deviation (NRMSD) of $\mathrm{NH}_{3}$ global burden among models is 1.17 and 0.33 with and without EMAC included. This drastic change in global burden NRMSD by EMAC is caused by its special treatment of wet deposition. In fact, the removal of trace gases and aerosol particles by clouds and precipitation in EMAC is not calculated based on empirically determined, fixed scavenging coefficients but rather by solving a system of coupled ordinary differential equations, explicitly describing the processes involved (Tost et al., 2006). This method resolves feedback mechanisms between the multi-phase chemistry and transport processes involved. The liquid phase reaction set used converts all the scavenged $\mathrm{NH}_{3}$ (or $\mathrm{HNO}_{3}$ ) into $\mathrm{NH}_{4}^{+}$(or $\mathrm{NO}_{3}^{-}$) in the liquid phase so that at the end everything that is deposited is the total $\mathrm{NH}_{4}^{+}$ and $\mathrm{NH}_{3}$.

Atmospheric $\mathrm{NH}_{4}^{+}$is produced entirely by $\mathrm{NH}_{3}$ chemical transformation. The models simulate $\mathrm{NH}_{4}^{+}$much closer in chemical production (difference less than a factor of 2) than in lifetime (difference up to a factor of 5.2), indicating removing rates are a key factor in controlling the global burden of $\mathrm{NH}_{4}^{+}$. For example, CHASER has a much longer lifetime of $\mathrm{NH}_{4}^{+}$(i.e., 9.8 days versus 4.3 days on average), which indicates a slow deposition removal of $\mathrm{NH}_{4}^{+}$from the atmosphere. Consequently, CHASER simulates a much higher atmospheric $\mathrm{NH}_{4}^{+}$burden than other models. 
Table 4. (a) $\mathrm{NO}_{3}^{-}$global budget for each model. (b) $\mathrm{NH}_{3}$ and $\mathrm{NH}_{4}^{+}$global budget for each model. (c) $\mathrm{HNO}_{3}$ global budget for each model. (d) $\mathrm{SO}_{4}^{2-}$ global budget for each model. "Avg" indicates the average values; "med" indicates the median values; "emi" indicates emissions.

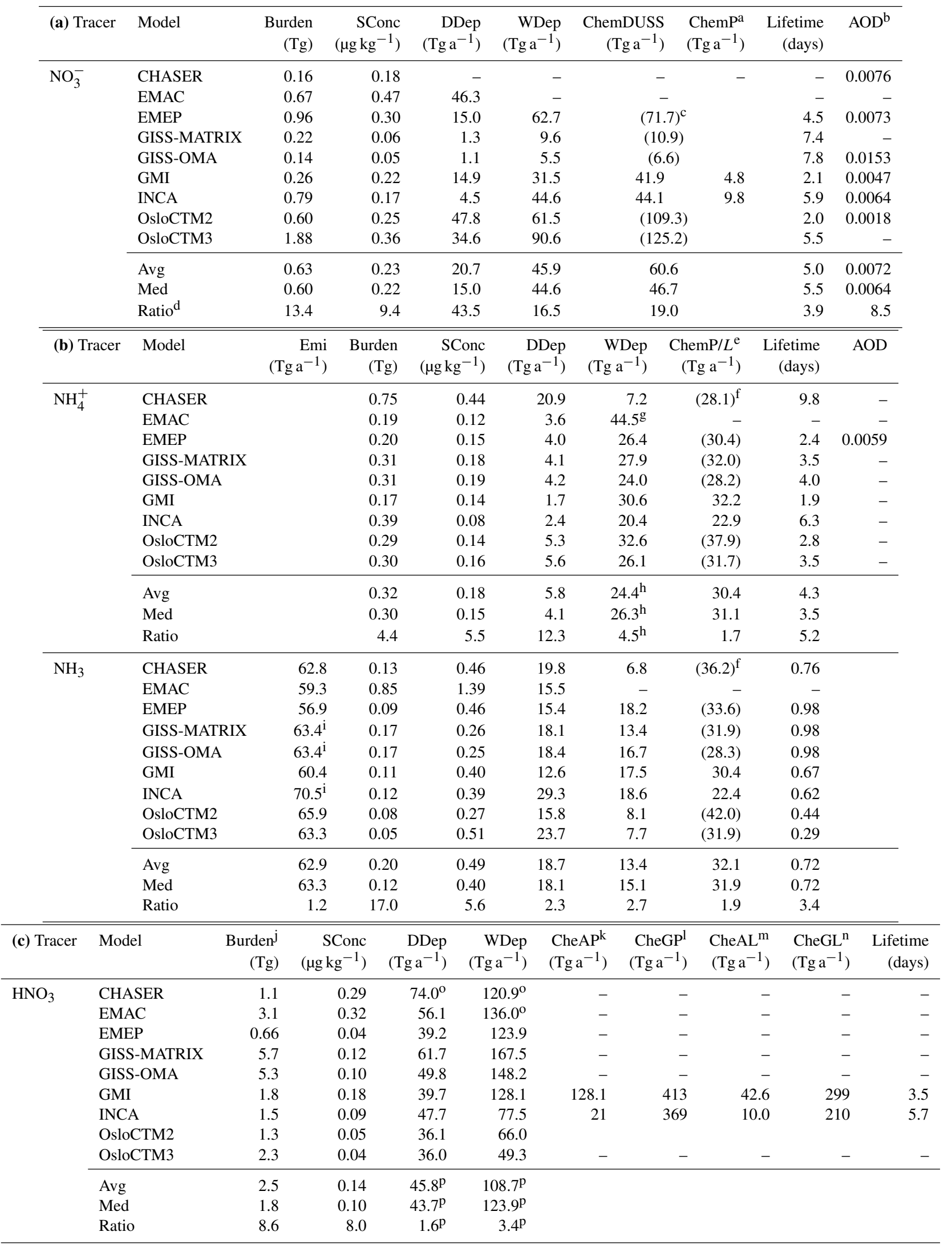


Table 4. Continued.

\begin{tabular}{|c|c|c|c|c|c|c|c|c|c|c|c|}
\hline (d) Tracer & Model & $\begin{array}{c}\text { Emi SO } \\
\left(\mathrm{Tg} \mathrm{a}^{-1}\right)\end{array}$ & $\begin{array}{c}\mathrm{Emi} \mathrm{SO}_{4} \\
\left(\mathrm{Tg} \mathrm{a}^{-1}\right)\end{array}$ & $\begin{array}{r}\text { Burden } \\
(\mathrm{Tg})\end{array}$ & $\begin{array}{r}\text { SConc } \\
\left(\mu \mathrm{kg}^{-1}\right)\end{array}$ & $\begin{array}{r}\text { DDep } \\
\left(\mathrm{Tg} \mathrm{a}^{-1}\right)\end{array}$ & $\begin{array}{r}\text { WDep } \\
\left(\mathrm{Tg} \mathrm{a}^{-1}\right)\end{array}$ & $\begin{array}{l}\text { Chem GP } \\
\quad\left(\mathrm{Tg} \mathrm{a}^{-1}\right)\end{array}$ & $\begin{array}{r}\text { Chem AqP } \\
\quad\left(\mathrm{Tg} \mathrm{a}^{-1}\right)\end{array}$ & $\begin{array}{r}\text { Lifetime } \\
\text { (days) }\end{array}$ & AOD \\
\hline \multirow[t]{8}{*}{$\mathrm{SO}_{4}^{2-}$} & CHASER & 111 & 0 & 3.3 & 1.44 & 22.1 & 137 & $(15$ & 59) & 7.6 & 0.0826 \\
\hline & GISS-MATRIX & 133 & 5.1 & 1.3 & 0.63 & 16.6 & 97 & (1) & 99) & 4.2 & - \\
\hline & GISS-OMA & 133 & 5.1 & 1.1 & 0.53 & 11.8 & 112 & 52.7 & 66.2 & 3.3 & 0.0714 \\
\hline & GMI & 111 & 0 & 1.1 & 0.58 & 7.5 & 205 & 126.5 & 86.1 & 3.6 & 0.0257 \\
\hline & OsloCTM3 & 133 & 4.1 & 2.7 & 0.55 & 20.2 & 160 & (17 & 76) & 5.5 & \\
\hline & $\mathrm{Avg}^{\mathrm{u}}$ & 122 & & 1.8 & 0.63 & 14.3 & 140 & 15 & 51 & 4.5 & 0.0469 \\
\hline & $\mathrm{Med}^{\mathrm{u}}$ & 133 & & 1.6 & 0.54 & 14.2 & 127 & 13 & 39 & 3.9 & 0.0392 \\
\hline & Ratio $^{\mathrm{u}}$ & 1.2 & & 4.0 & 4.2 & 2.9 & 2.1 & 2 & 0 & 3.0 & 3.6 \\
\hline
\end{tabular}

${ }^{\text {a }}$ ChemP refers to $\mathrm{NO}_{3}^{-}$chemical production associated with $\mathrm{NH}_{3} / \mathrm{NH}_{4}^{+}$.

b AOD here includes $\mathrm{NH}_{4}^{+}$that is associated with $\mathrm{NO}_{3}^{-}$for all models expect EMEP.

${ }^{\mathrm{c}}$ Value inside parentheses is estimated total $\mathrm{NO}_{3}^{-}$chemical production based on its total loss, while budget without parentheses is reported directly by model.

d A ratio of maximum to minimum model simulations.

e $C h e m P / L$ : chemical production or loss term.

${ }^{\mathrm{f}}$ Chemical budgets inside parentheses are inferred based on the reported emission and total deposition.

g EMAC gives total wet deposition of $\mathrm{NH}_{4}^{+}$and $\mathrm{NH}_{3}$.

${ }^{\mathrm{h}}$ Statistic values of $\mathrm{NH}_{4}^{+}$wet deposition do not include EMAC.

${ }^{\mathrm{i}}$ INCA uses ECLIPSE anthropogenic emissions, two GISS models use CMIP5 anthropogenic emission, and all other models use HTAPv2 anthropogenic emissions.

$\mathrm{j} \mathrm{HNO}_{3}$ burden for the atmosphere up to $100 \mathrm{hPa}$.

k CheAP: chemistry production from aerosol phase.

${ }^{1}$ CheGP: chemistry production from gas phase.

m CheAL: chemistry loss from aerosol phase.

${ }^{n}$ CheGL: chemistry loss from gas phase.

${ }^{\circ}$ For both $\mathrm{HNO}_{3}$ and $\mathrm{NO}_{3}^{-}$.

p Statistical values do not include CHASER and EMAC that report total dry or wet deposition of $\mathrm{HNO}_{3}$ and $\mathrm{NO}_{3}^{-}$.

q ChemGP: chemistry production from gas phase reaction.

${ }^{\mathrm{r}}$ ChemAqP: chemistry production from aqueous phase reaction.

${ }^{s}$ EMAC emission also includes sea spray $\mathrm{SO}_{4}^{2-}$.

${ }^{\mathrm{t}}$ EMAC dry deposition includes sedimentation, and $\mathrm{SO}_{4}^{2-}$ sedimentation is very high since it has assumed that $7.7 \%$ of sea salt is $\mathrm{SO}_{4}^{2-}$.

u Statistical values do not include EMAC.

\subsection{2 $\mathrm{HNO}_{3}$ and $\mathrm{NO}_{3}^{-}$}

$\mathrm{HNO}_{3}$, an important nitrate precursor, differs by up to a factor of 9 in its global tropospheric burden among the models (Table 4c). All models simulated $\mathrm{HNO}_{3}$ based on a full gas phase $\mathrm{O}_{3}-\mathrm{HO}_{x}-\mathrm{NO}_{x}$ chemistry and coupled it with aerosol chemistry. This $\mathrm{HNO}_{3}$ diversity will naturally be propagated into the $\mathrm{NO}_{3}^{-}$simulation. However, further discussion of the detailed consideration of full gas-aerosol chemistry for $\mathrm{HNO}_{3}$ diversity among the models is beyond the scope of this study.

The resultant aerosol product (i.e., $\mathrm{NO}_{3}^{-}$) does not entirely follow its precursor (i.e., $\mathrm{HNO}_{3}$ ) in terms of global burden: EMEP has very low $\mathrm{HNO}_{3}$ but high $\mathrm{NO}_{3}^{-}$; two GISS models (MATRIX and OMA) simulate high $\mathrm{HNO}_{3}$ but low $\mathrm{NO}_{3}^{-}$, while OsloCTM3 has an average $\mathrm{HNO}_{3}$ but more than triple the average $\mathrm{NO}_{3}^{-}$(Table 4a and c). Furthermore, the difference in $\mathrm{NO}_{3}^{-}$global burden (up to a factor of 13) is larger than that of $\mathrm{HNO}_{3}$. Differences in chemical mechanisms of $\mathrm{NO}_{3}^{-}$ production could be a potential explanation along with the difference in $\mathrm{HNO}_{3}$ precursor. Unfortunately, only GMI and INCA provide a detailed $\mathrm{NO}_{3}^{-}$chemistry budget analysis.
Nevertheless, we can infer that the total chemical production of $\mathrm{NO}_{3}^{-}$must be very low $(\sim 10 \mathrm{Tg})$ in the two GISS models and very high $(>100 \mathrm{Tg})$ in OsloCTM2 and OsloCTM3 based on the reported total $\mathrm{NO}_{3}^{-}$loss. Combining this information with the $\mathrm{HNO}_{3}$ global tropospheric burden (Table $4 \mathrm{c}$ ), we can further infer that the chemical conversion from $\mathrm{HNO}_{3}$ to $\mathrm{NO}_{3}^{-}$must be lowest in the two GISS models and highest in the two Oslo models. Several factors could influence this conversion, such as the availability of alkaline species of mineral dust and sea salt particles and the physicochemical mechanism of nitrate formation on dust and sea salt, availability of $\mathrm{NH}_{3}$ after combining with $\mathrm{SO}_{4}^{2-}$, and the atmospheric meteorological fields of temperature and relative humidity. More discussions are given in Sect. 5.2 and 5.3.

Atmospheric lifetime of $\mathrm{NO}_{3}^{-}$differs up to a factor of 4, from about 2 days in GMI and OsloCTM2 to more than 7 days in GISS-OMA and GISS-MATRIX. The slower removal processes in the two GISS models compensate the low chemical production and help to maintain their $\mathrm{NO}_{3}^{-}$atmospheric burden (Fig. 3 and Table 4a). 
(a)

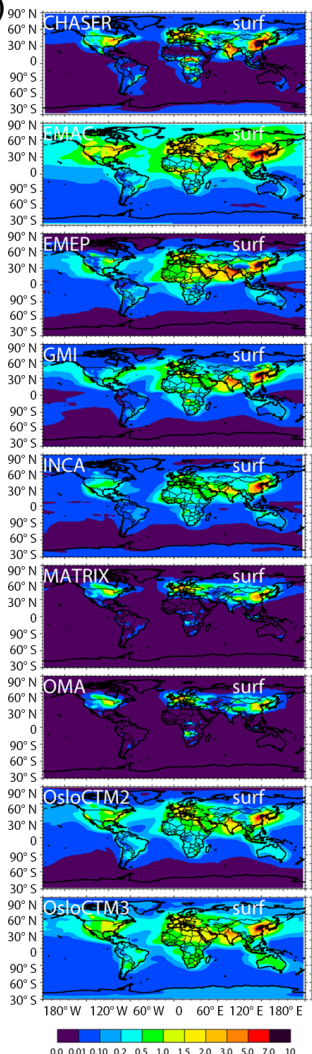

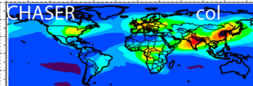
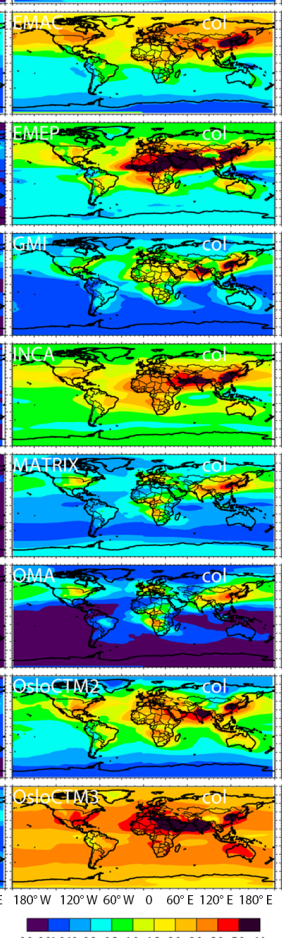

(b)

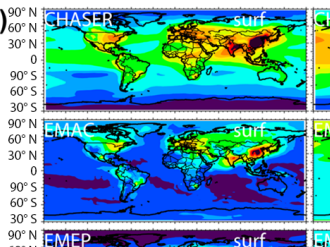

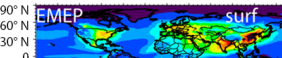

$90^{\circ} \mathrm{S}$
$60^{\circ} 5$
$30^{\circ} \mathrm{S}$

as

$30^{\circ} 5$

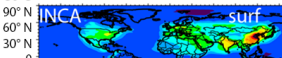

0
$90^{\circ} \mathrm{s}$
$60^{\circ} \mathrm{S}$
$30^{\circ} \mathrm{s}$

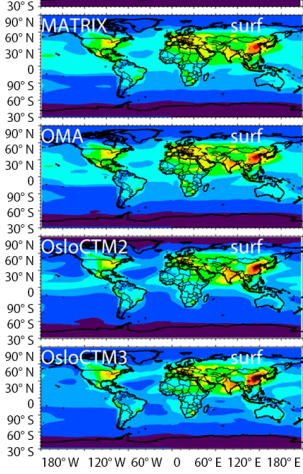

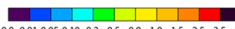
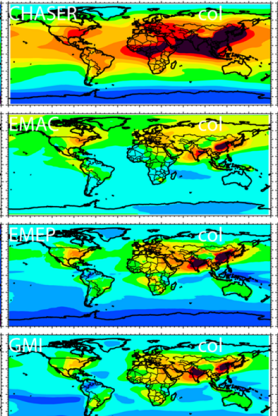

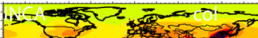
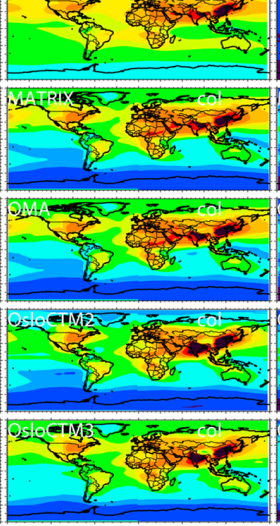

W
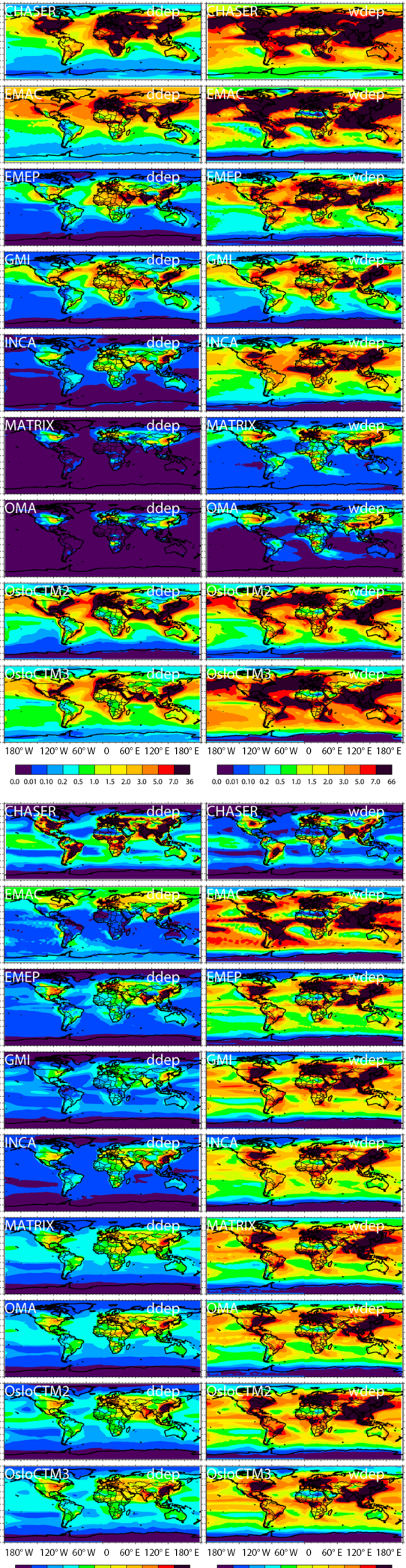

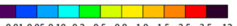
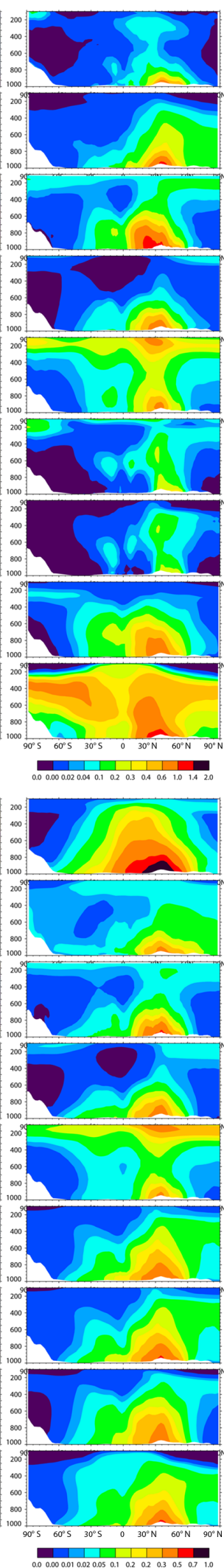

Figure 3. 

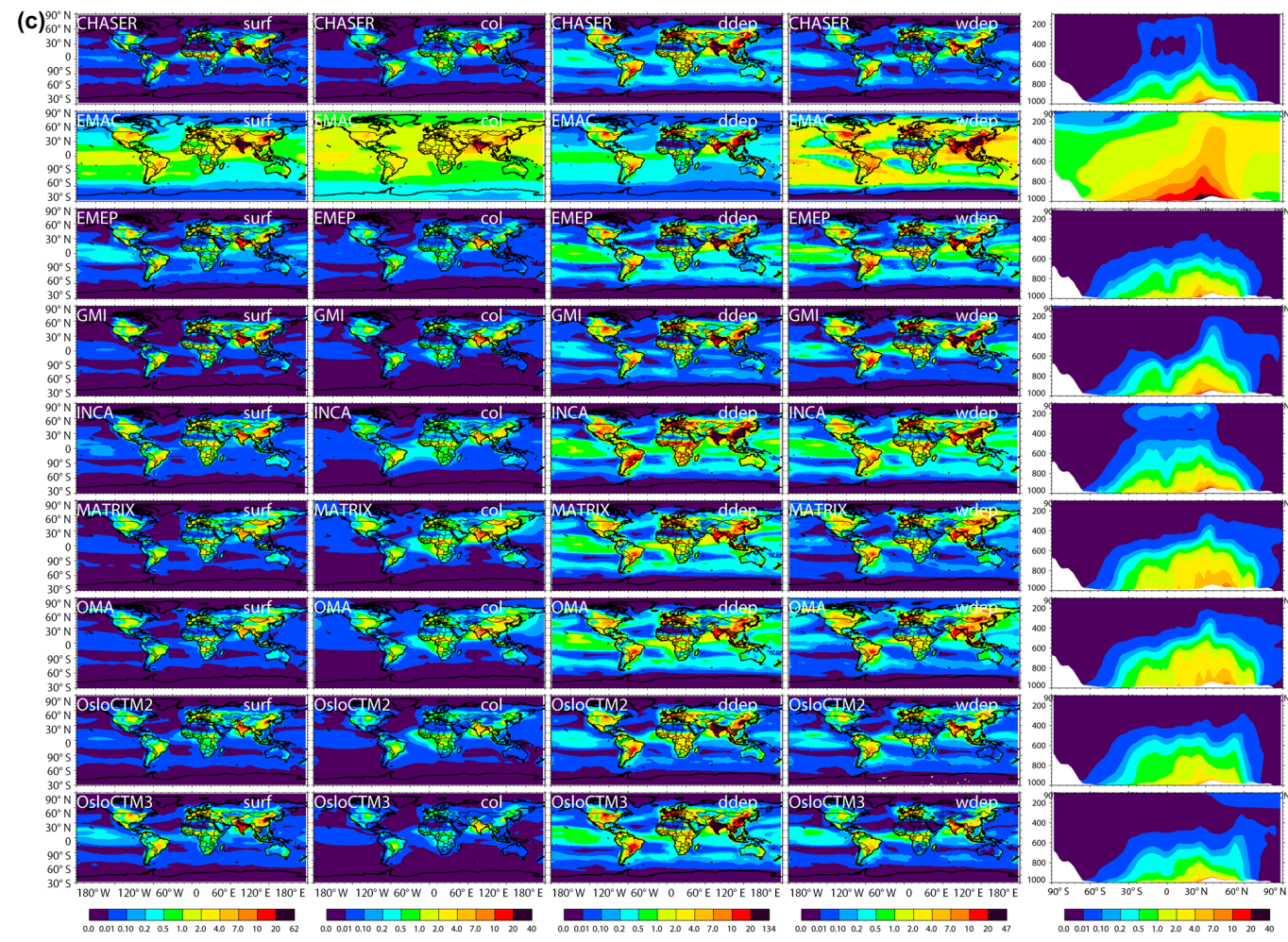

(d)
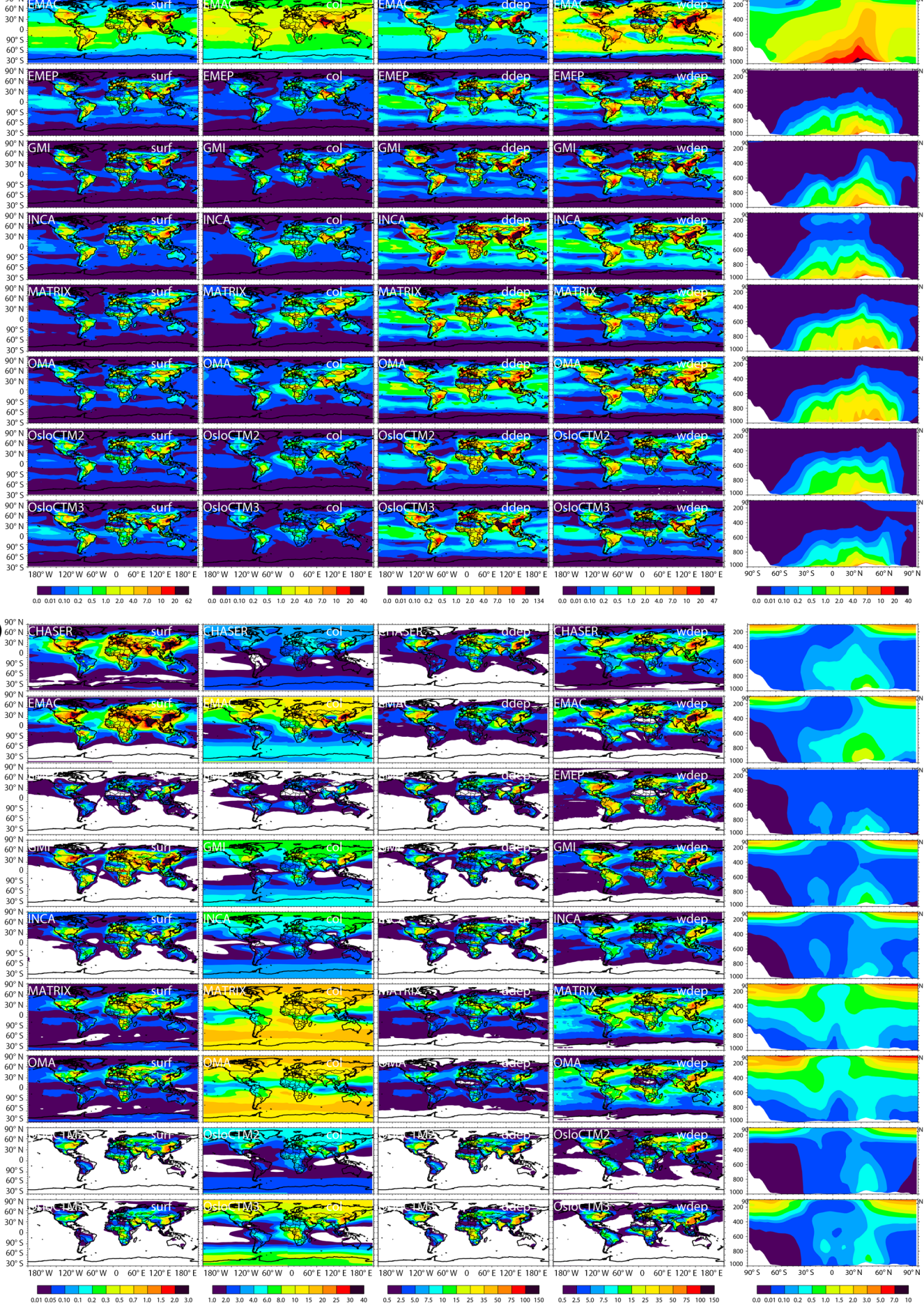

Figure 3. (a) Multi-model comparison of $\mathrm{NO}_{3}^{-}$for the surface mass mixing ratio $\left(\mu \mathrm{g} \mathrm{kg}^{-1}\right.$, first column), column load ( $\mathrm{mg} \mathrm{m}^{-2}$, second column), dry deposition (ng m ${ }^{-2} \mathrm{~s}^{-1}$, third column), wet deposition ( $\mathrm{ng} \mathrm{m}^{-2} \mathrm{~s}^{-1}$, fourth column), and vertical zonal mean $\left(0.5 \mathrm{\mu g} \mathrm{kg}^{-1}\right.$, fifth column). Note that the CHASER dry and wet depositions and the EMAC wet deposition in this figure contain both $\mathrm{NO}_{3}^{-}$and $\mathrm{HNO}_{3}$, while the rest of the models contain $\mathrm{NO}_{3}^{-}$. Panel (b) is the same as (a) but for $\mathrm{NH}_{4}^{+}$and the unit in vertical distribution is $\mu \mathrm{g} \mathrm{kg}^{-1}$. Note that the EMAC wet deposition in this figure contains both $\mathrm{NH}_{4}^{+}$and $\mathrm{NH}_{3}$, while the rest of the models contain only $\mathrm{NH}_{4}^{+}$. Panel (c) is the same as (a) but for $\mathrm{NH}_{3}$. Units are ppb for surface concentration and $0.1 \mathrm{ppb}$ for vertical distribution. Note that the EMAC wet deposition in this figure contains both $\mathrm{NH}_{3}$ and $\mathrm{NH}_{4}^{+}$, while the rest of the models contain only $\mathrm{NH}_{3}$. Panel (d) is the same as (a) but for $\mathrm{HNO}_{3}$. Units are $100 \mathrm{ppb}$ for surface concentration, $\mathrm{mg} \mathrm{m}^{-2}$ for loading, and $2 \mathrm{ng} \mathrm{m}^{-2} \mathrm{~s}^{-1}$ for dry and wet depositions. Note that the column total of $\mathrm{HNO}_{3}$ is from the surface up to $100 \mathrm{ppb}$ vertically. The CHASER dry and wet depositions and the EMAC wet deposition in this figure contain both $\mathrm{HNO}_{3}$ and $\mathrm{NO}_{3}^{-}$, while the rest of the models contain only $\mathrm{HNO}_{3}$. 


\subsection{Model-observation comparisons}

\subsubsection{Comparisons of surface concentrations over North America, Europe, and east Asia}

Understanding diversity among model simulations and potential physiochemical processes behind the difference is important but not sufficient. The information has to be combined with the knowledge of model performance obtained directly from comparisons, particularly down to the process level, against various measurements to gain an understanding of the direction of any improvement. Figure $4 \mathrm{a}-\mathrm{c}$ show a model-observation comparison for surface mass/volume mixing ratios of $\mathrm{NO}_{3}^{-}, \mathrm{NH}_{4}^{+}, \mathrm{NH}_{3}, \mathrm{HNO}_{3}$, and $\mathrm{SO}_{4}^{2-}$ over North America (CastNET), Europe (EMEP), and east Asia (EANET). Each point represents a monthly mean concentration at one observational site. Generally, the agreement between model and observation is better for aerosol components than for gas tracers (i.e., the precursor species $\mathrm{NH}_{3}$ and $\mathrm{HNO}_{3}$ ) over all three regions. All models underestimate $\mathrm{NH}_{3}$ surface volume mixing ratio with a ratio of model to observation down to 0.14 , while most models overestimate surface $\mathrm{HNO}_{3}$ volume mixing ratio with a ratio up to 3.9 over North America. The worse performances of $\mathrm{NH}_{3}$ against observations may be also associated with their relatively lower measurement accuracy, i.e., easier to be contaminated during measurement (Williams et al., 1992). Among aerosol simulations, model performance is very similar for $\mathrm{NH}_{4}^{+}$and $\mathrm{SO}_{4}^{2-}$, while slightly worse for $\mathrm{NO}_{3}^{-}$that is dispersed further away from the $1: 1$ line, particularly at low $\mathrm{NO}_{3}^{-}$values. The $\mathrm{NO}_{3}^{-}$ simulation over east Asia is worst, with the average normalized root mean square being 1.3 and 1.8 times higher than that over North America and Europe, respectively.

\subsubsection{Comparisons of vertical profiles with aircraft measurements during the ARCTAS field campaign}

Evaluation of model performance presented in Sect. 4.2.1 for the surface concentrations in the source regions is highly dependent on the accuracy of the emission inventory. On the other hand, evaluation using aircraft measurements, particularly over remote regions, provides further examination of models' physicochemical evolution during transport. Here, we use data from three phases of the ARCTAS aircraft campaign (Sect. 3), and the results are shown in Fig. 5. All model results of $\mathrm{NO}_{3}^{-}, \mathrm{NH}_{4}^{+}$, and $\mathrm{SO}_{4}^{2-}$ are sampled along the flight track and averaged regionally within $1 \mathrm{~km}$ vertically for each campaign phase before comparing with the corresponding aircraft measurements. Note that only EMAC, EMEP, and GMI report daily 3-D global tracer concentrations, while the others report monthly only. Note also that only EMEP and GMI adopt daily biomass burning emissions, while the others use monthly emissions. To verify the representativeness of monthly mean concentration in capturing the main fea- tures exhibited in model-observation comparisons, daily and monthly concentrations of the three models are used in the same spatial sampling to compare with the measurements (see the green lines for daily and red for monthly concentrations in the figure). The comparison keeps its main features as shown when using both daily and monthly model data.

During ARCTAS-A, which was conducted in April 2008 and was based in Fairbanks, Alaska, none of the models captured the long-range transport of aerosols primarily from Asia, which entered the polar regions at altitudes between 2 and $7 \mathrm{~km}$ (Fig. 3 in Bian et al., 2013). Except CHASER and EMAC, all models also report a significant underestimation of $\mathrm{NH}_{4}^{+}$and $\mathrm{SO}_{4}^{2-}$ in the boundary layer. A previous assessment of pollution transport to the Arctic indicated that aerosol wet removal plays an important role in the uncertainty of Arctic aerosols (Shindell et al., 2008). Another potential reason is that some large fire activities in Siberia during April 2008 (Jacob et al., 2010) may be missed in the GFED3 emission inventory. The underestimation of $\mathrm{SO}_{4}^{2-}$ may help bring up $\mathrm{NO}_{3}^{-}$production, particularly at high altitudes. During ARCTAS-CARB, which was conducted in June 2008 and based in Palmdale, California, agreement between model and measurements is much improved. Almost all models show a rapid vertical decrease from the surface to the free troposphere, which is consistent with the measurements of $\mathrm{SO}_{4}^{2-}$ and $\mathrm{NH}_{4}^{+}$but not $\mathrm{NO}_{3}^{-}$. The observation shows a maximum of $\mathrm{NO}_{3}^{-}$at about $1.5 \mathrm{~km}$, which is not represented by any of the models. During ARCTAS-B, which was conducted in July 2008 and was based in Cold Lake, Canada, when there were frequent local wildfires, model performance was mixed. In general, most models underestimated concentrations of $\mathrm{NO}_{3}^{-}, \mathrm{NH}_{4}^{+}$, and $\mathrm{SO}_{4}^{2-}$ below $4 \mathrm{~km}$. The CHASER model is special in that it overestimates $\mathrm{SO}_{4}^{2-}$ significantly. This may contribute to high (near surface) to comparable (free troposphere) model simulation of $\mathrm{NH}_{4}^{+}$but an underestimation of $\mathrm{NO}_{3}^{-}$. Different from other models, the INCA model shows an enhancement of pollutants in the upper troposphere with concentrations much higher (more than 5 times) than observations. This behavior may be derived from a very vigorous vertical uplifting to the upper troposphere as revealed from Fig. 3a-b, combined with a low $\mathrm{NH}_{3}$ Henry's law constant used by INCA; see discussion in Sect. 5.2.

Note that all measurements and model data we discussed above are for fine-mode aerosols. Total $\mathrm{NO}_{3}^{-}$(orange line using monthly model output) is also shown in the figure to reveal whether a change of partitioning of fine- and coarsemode $\mathrm{NO}_{3}^{-}$could improve the model-observation comparison. It seems that the new version of OsloCTM3 may put too much $\mathrm{NO}_{3}^{-}$in the coarse mode. 

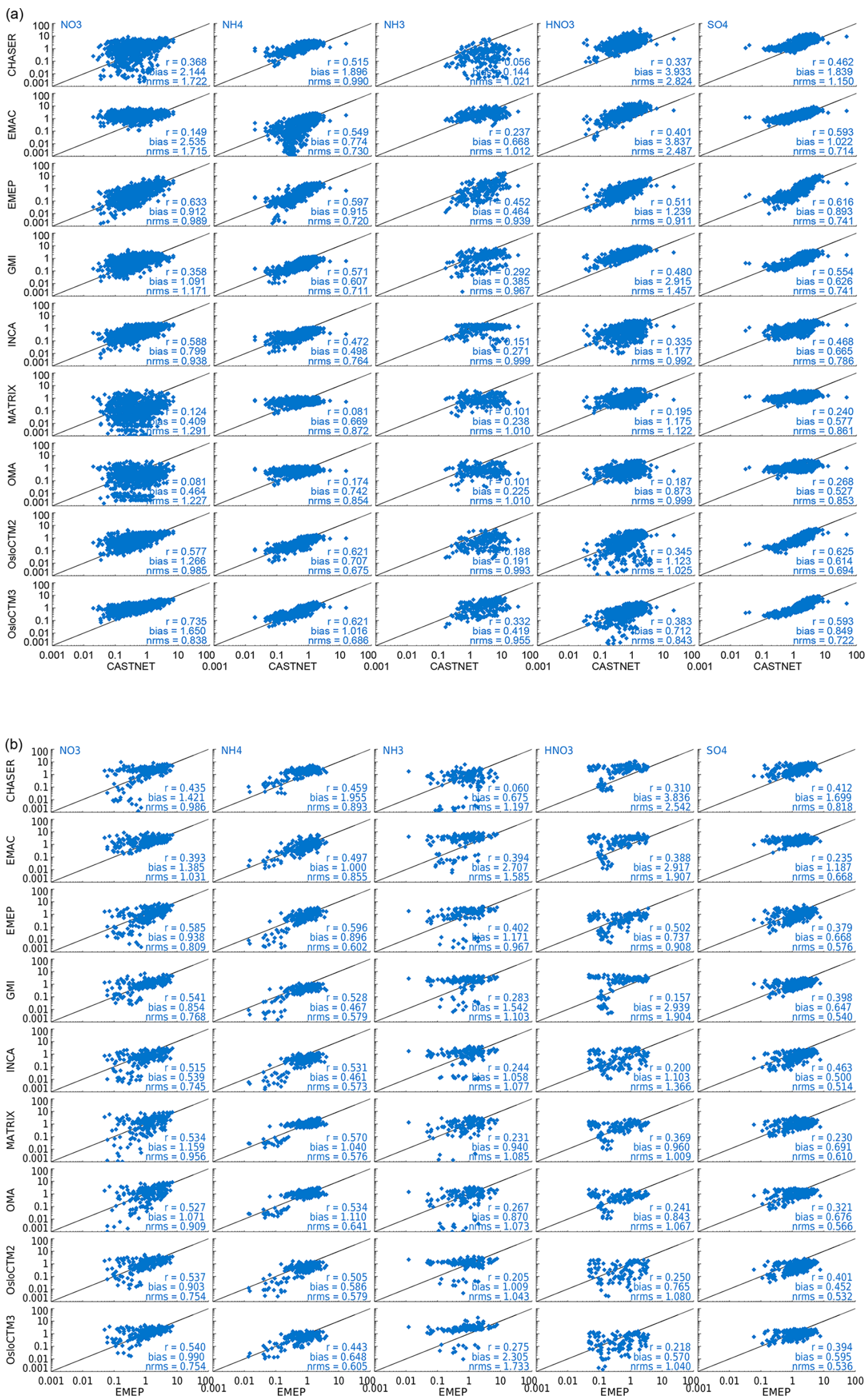

Figure 4. 


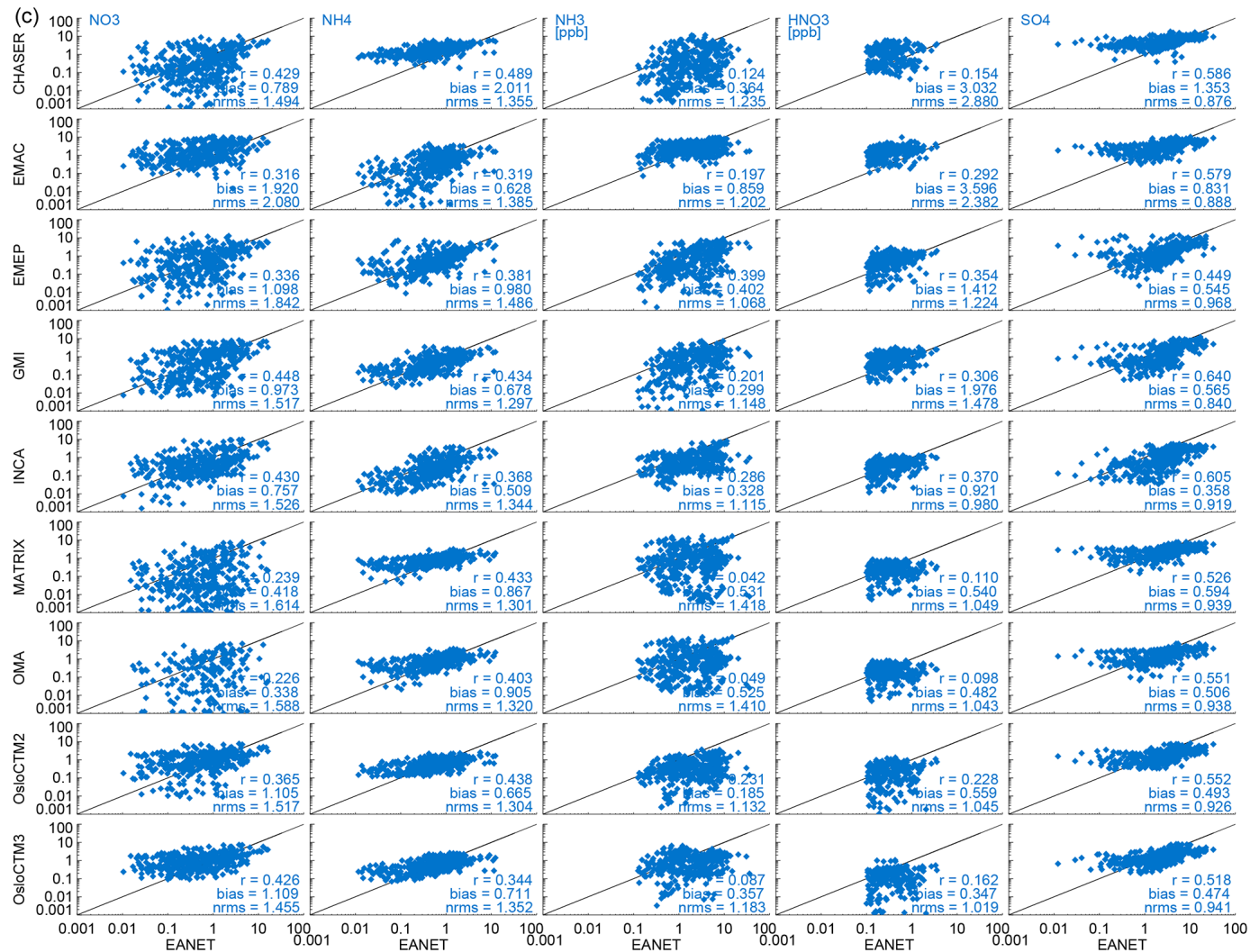

Figure 4. (a) Comparison of surface mixing ratios of $\mathrm{NO}_{3}^{-}, \mathrm{NH}_{4}^{+}, \mathrm{NH}_{3}, \mathrm{HNO}_{3}$, and $\mathrm{SO}_{4}^{2-}$ between models and CASTNET measurement. Units are $\mu \mathrm{g} \mathrm{m}^{-3}$. Panel (b) is the same as (a) but for EMEP. Panel (c) is the same as (a) but for EANET.
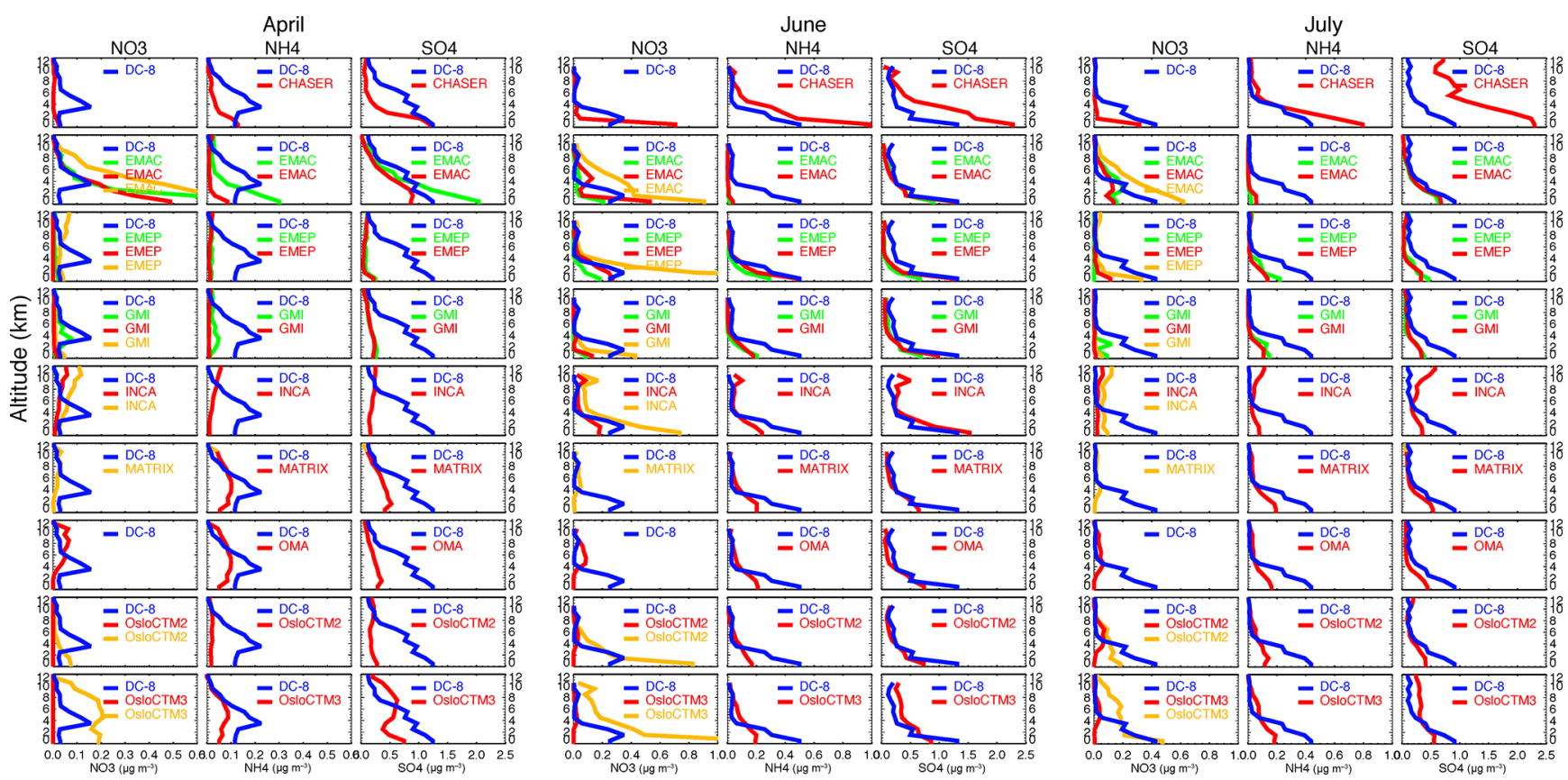

Figure 5. Vertical profile comparison between ARCTAS aircraft measurements and AeroCom model simulations. Note that ARCTAS AMS measurements give fine-mode aerosols. Model profiles are shown in green (fine-mode aerosol analyzed with daily output), red (fine-mode aerosol with monthly output), and orange (total $\mathrm{NO}_{3}^{-}$with monthly output). CHASER and OMA have fine-mode $\mathrm{NO}_{3}^{-}$only. Units are $\mu \mathrm{g} \mathrm{m}{ }^{-3}$. 


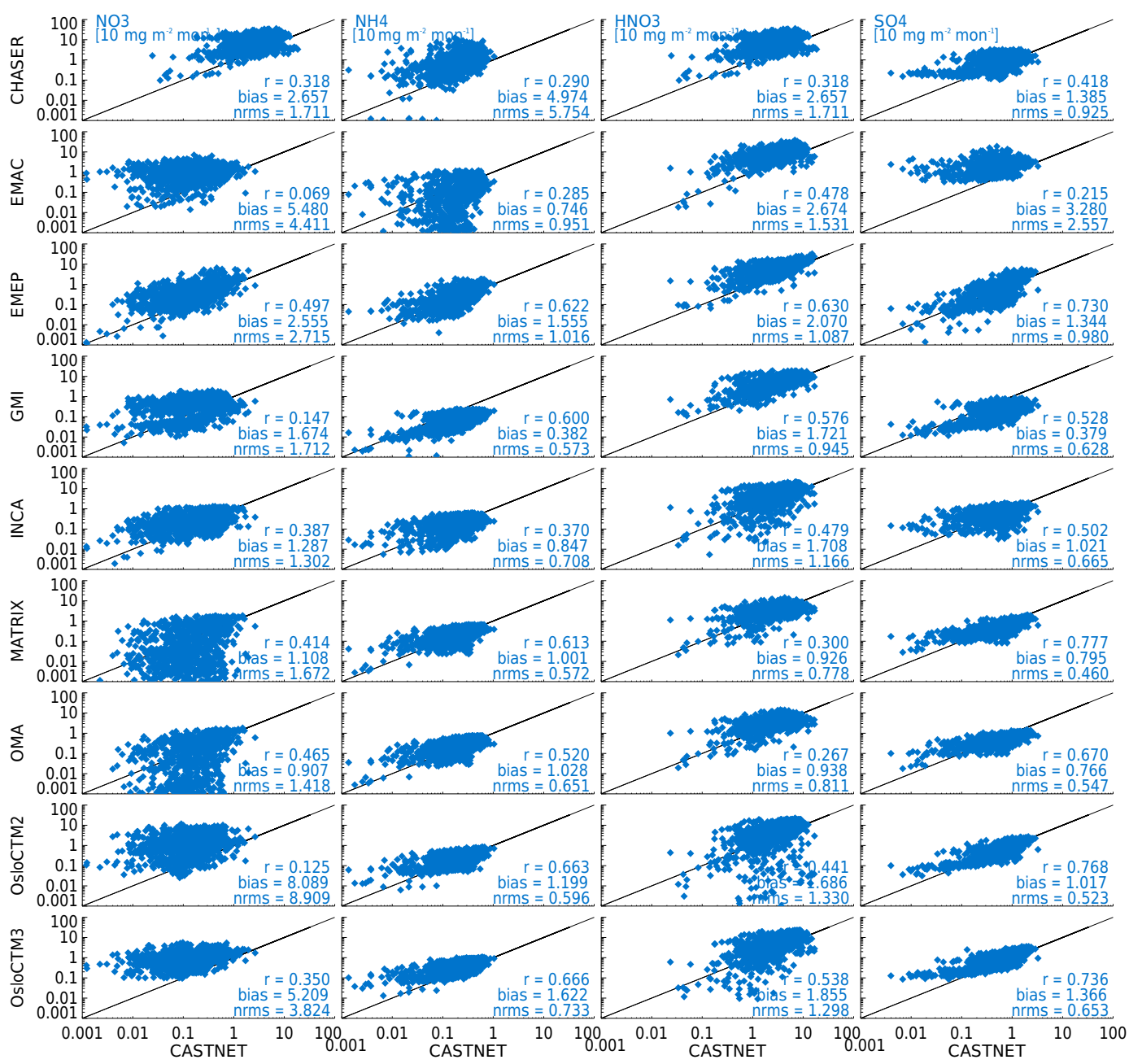

Figure 6. Comparison of surface dry deposition of $\mathrm{NO}_{3}^{-}, \mathrm{NH}_{4}^{+}, \mathrm{HNO}_{3}$, and $\mathrm{SO}_{4}^{2-}$ between models and CASTNET measurements. Units are $10 \mathrm{mg} \mathrm{m}^{-2} \mathrm{mon}^{-1}$.

\subsection{Model-observation comparison for dry and wet deposition}

\subsubsection{Dry deposition}

The budget analysis in Sect. 4.1 concluded that dry and/or wet depositions are most likely the main processes driving the diversity in the model simulations. Thus, further evaluation of deposition processes is needed to identify any potential problematic model.

The dry depositions of $\mathrm{NO}_{3}^{-}, \mathrm{NH}_{4}^{+}, \mathrm{HNO}_{3}$, and $\mathrm{SO}_{4}^{2-}$ simulated by the models are compared against CASTNET measurements over North America (Fig. 6). Generally, the overestimation of surface $\mathrm{HNO}_{3}$ concentrations (Fig. 3a) results in the higher dry depositions of $\mathrm{HNO}_{3}$, but this is not the case for $\mathrm{NO}_{3}^{-}$. Meanwhile, most of the models give a better dry deposition simulation for aerosol $\mathrm{SO}_{4}^{2-}$ and $\mathrm{NH}_{4}^{+}$ than for aerosol $\mathrm{NO}_{3}^{-}$, except CHASER. Specifically, GISSOMA and GISS-MATRIX have widespread dry $\mathrm{NO}_{3}^{-}$de- position at any given measurement value. In other words, the two models underestimate $\mathrm{NO}_{3}^{-}$dry deposition significantly at many observational stations, which does not occur in the other models. This low dry deposition simulation may occur outside North America as well because the global dry depositions of the two models are lower than others (Table 4a). OsloCTM2 overestimates $\mathrm{NO}_{3}^{-}$dry deposition significantly, which is probably linked to its larger coarse fraction of the nitrate aerosol (see discussion in Sect. 5.3). OsloCTM3 improved its dry deposition scheme although the model still overestimates the dry deposition. We will discuss the OsloCTM2 $\mathrm{NO}_{3}^{-}$simulation over North America by combining the model's wet deposition in the next section. $\mathrm{NH}_{4}^{+}$dry deposition is low in GMI but very high in CHASER. This performance is also extended globally as summarized in Table $4 \mathrm{~b}$. 


\subsubsection{Wet deposition}

The wet deposition simulations from the nine models are compared with surface measurement over North America (Fig. 7a) and east Asia (Fig. 7b) for oxidized $\mathrm{NO}_{3}^{-}$(i.e., total $\mathrm{NO}_{3}^{-}$and $\left.\mathrm{HNO}_{3}\right)$, total $\mathrm{NH}_{4}^{+}$and $\mathrm{NH}_{3}\left(\mathrm{tNH}_{4}^{+}\right)$, and $\mathrm{SO}_{4}^{2-}$. All models tend to underestimate the wet deposition of $\mathrm{tNH}_{4}^{+}$ and $\mathrm{SO}_{4}^{2-}$ over the two regions. EMAC, GMI, OsloCTM2, and OsloCTM3 have relatively high wet removal for oxidized $\mathrm{NO}_{3}^{-}$, while EMEP removes much less than the others over North America. All models' wet deposition of oxidized $\mathrm{NO}_{3}^{-}$is biased low over east Asia. As we discussed above, OsloCTM2 and OsloCTM3 have very high dry $\mathrm{NO}_{3}^{-}$depositions (Fig. 6) compared to CASTNET observations. The overall high dry and wet $\mathrm{NO}_{3}^{-}$depositions along with high atmospheric concentrations (Fig. 4a) indicate that the chemical formation of $\mathrm{NO}_{3}^{-}$in the two models must be also high. This performance might be also true on a global scale since the inferred chemical productions of $\mathrm{NO}_{3}^{-}$in the two models are the highest (Table 4a). CHASER has the lowest $\mathrm{tNH}_{4}^{+}$ wet deposition. This may result in a very high $\mathrm{NH}_{4}^{+}$dry deposition (Fig. 6) and concentration (Figs. 4a-c, 5) compared to observations and other models. Overall, wet deposition seems to be the dominant process in determining the diversity in $\mathrm{NH}_{3}$ and $\mathrm{NH}_{4}^{+}$lifetime (Table $4 \mathrm{~b}$ ).

Note that we use the traditional approach of comparing models' grid-box mean values with observations, which does not take into account the impact of the models' horizontal resolutions in their representation of observations (Schutgens et al., 2016). Since majority models (except EMEP) have horizontal resolutions around $2-3^{\circ}$, the models' grid-box means tend to smooth out extreme (i.e., very low or high) observations. Consequently, the slopes of the fitting lines are generally less than 1 on the scattering plots with the model as the $y$ axis and the observations as the $x$ axis (e.g., Figs. 4a-d, 6, 7a-b).

\section{Discussion of major uncertainties in nitrate formation}

Large uncertainties of nitrate studies result from the complexity of the simulations which must consider a comprehensive $\mathrm{NO}_{x}-\mathrm{NMHC}-\mathrm{O}_{3}-\mathrm{NH}_{3}$ chemistry and a thermodynamic equilibrium model (TEQM) to partition semi-volatile ammonium nitrate between the gas and aerosol phases. Nitrate aerosol concentrations depend on temperature, $\mathrm{RH}$, and concentrations of $\mathrm{HNO}_{3}, \mathrm{NH}_{3}, \mathrm{NH}_{4}^{+}, \mathrm{SO}_{4}^{2-}, \mathrm{Cl}^{-}, \mathrm{Na}^{+}, \mathrm{Ca}^{2+}$, $\mathrm{K}^{+}, \mathrm{Mg}^{2+}$, and organic acids, among others. A further complicating factor is that the equilibrium for the coarse mode is somewhat questionable (Feng and Penner, 2007). In addition, wet removal of $\mathrm{NH}_{3}$ is very sensitive to the $\mathrm{pH}$ in cloud water. We will discuss some of these uncertainties below.

\section{1 pH-dependent $\mathrm{NH}_{3}$ wet deposition}

Gas tracer $\mathrm{NH}_{3}$, a precursor of ammonium aerosol, experiences atmospheric wet deposition, and its deposition rate is typically calculated using Henry's law. Henry's law constant $(H)$ of gases in water is usually given at $298 \mathrm{~K}$ (indicated by $\Theta$ in superscript) and can be adjusted by temperature $(T)$.

$H(T)=H^{\Theta} \times \exp \left(-\frac{\Delta H_{\mathrm{sol}}}{R}\left(\frac{1}{T}-\frac{1}{T^{\Theta}}\right)\right)$

Here, $\Delta \mathrm{H}_{\text {sol }}$ is the enthalpy of dissolution and $R$ is the gas constant.

For some acidic/basic gases, including $\mathrm{NH}_{3}$, Henry's law constant is also a function of $\mathrm{pH}$ in cloud water (also known as effective Henry's law constant $H^{\Theta *}$ ). As explained in the Appendix, the $H^{\Theta *}$ is inferred from $H^{\Theta}$ with a correction of $\mathrm{pH}\left(\mathrm{pH}=-\log _{10}\left[H^{+}\right]\right)$as

$H^{\Theta *}=H^{\Theta} \frac{K_{\mathrm{al}}\left[H^{+}\right]}{K_{\mathrm{W}}}$.

Here, $K_{\mathrm{al}} \approx 1.8 \times 10^{-5}$ and $K_{\mathrm{w}}=1.0 \times 10^{-14}$ at $298 \mathrm{~K}$ in pure water (see the Appendix). However, not every model accounts for $\mathrm{pH}$ adjustment (i.e., the reaction of Eq. A2 in the Appendix) for $\mathrm{NH}_{3}$ dissolution. More accurately, the EMAC model implicitly calculates the effective Henry's law constant by solving a set of partial differential equations, which includes not only the gas-liquid phase equilibria but also the reactions in the liquid phase (i.e., dissociation or acid-base equilibria, redox reactions, and photolysis reactions in the liquid phase; see Tost et al., 2006). Therefore, the gas-liquid phase equilibrium is explicitly calculated based on the chemical mechanism used in the liquid phase. As listed in Table 5, the rest of the models are generally divided into two groups based on their effective Henry's law constant: (1) INCA, GISS-OMA, and GISS-MATRIX have $H^{\Theta *} \leq 100\left(L^{\Theta}\right.$ without $\mathrm{pH}$ correction) and (2) CHASER, GMI, OsloCTM2, and OsloCTM3 have $H^{\Theta *}>10^{+5}\left(H^{\Theta}\right.$ with $\mathrm{pH}$ correction). The $\mathrm{NH}_{3}$ 's $H^{\Theta *}$ adopted by the models varies dramatically, up to an order of 6 in magnitude among all the models and a factor of 10 just for the models in $H^{\Theta}$ group (Table 5). The latter corresponds to a range of $\mathrm{pH}$ from 4.5 (OsloCTM2) to 5.5 (CHASER).

To examine how sensitive $\mathrm{NH}_{3}, \mathrm{NH}_{4}^{+}$, and $\mathrm{NO}_{3}^{-}$simulations are in response to the magnitude of $\mathrm{NH}_{3}$ 's $H^{\Theta *}$, we performed a sensitivity experiment, named TWET, in the GMI model in which there was no $\mathrm{pH}$ adjustment for $\mathrm{NH}_{3}$ Henry's law constant (i.e., $H^{\Theta *}=61$ instead of $1.05 \times 10^{6}$; see Table 6). The resultant annual budgets of dry/wet deposition, chemistry production and loss, and atmospheric loading of $\mathrm{NH}_{3}, \mathrm{NH}_{4}^{+}$, and $\mathrm{NO}_{3}^{-}$are summarized in Table 7 , the tracers' vertical zonal mean distributions are shown in Fig. 8, and the comparisons with the ARCTAS measurements for $\mathrm{NH}_{4}^{+}$ and $\mathrm{NO}_{3}^{-}$are shown in Fig. 9. For convenient comparison, the GMI baseline results are given in the table and figures 

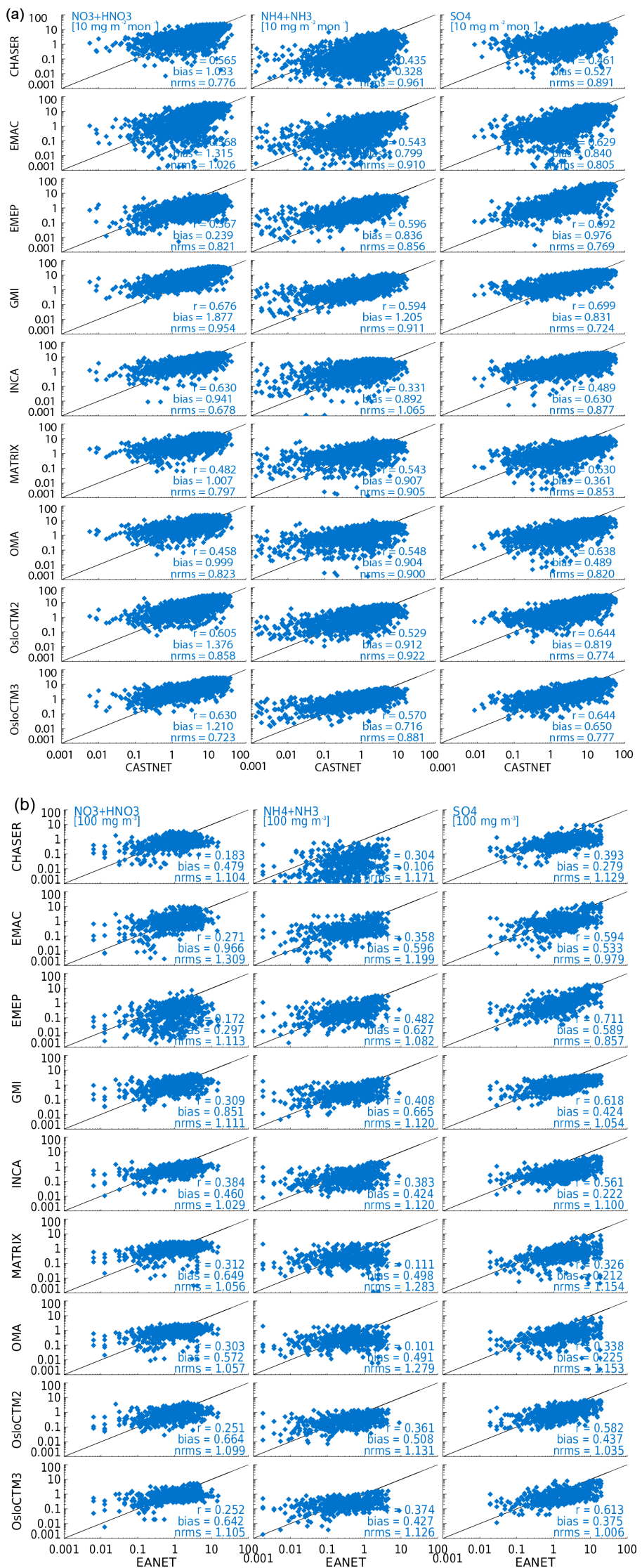

Figure 7. (a) Comparison of surface wet deposition of $\mathrm{NO}_{3}^{-}+\mathrm{HNO}_{3}, \mathrm{NH}_{4}^{+}+\mathrm{NH}_{3}$, and $\mathrm{SO}_{4}^{2-}$ between models and NDAP NTN measurements. Units are $10 \mathrm{mg} \mathrm{m}{ }^{-2}$ mon ${ }^{-1}$ Panel (b) is the same as (a) but for EANET with units of $100 \mathrm{mg} \mathrm{m}^{-3}$. 

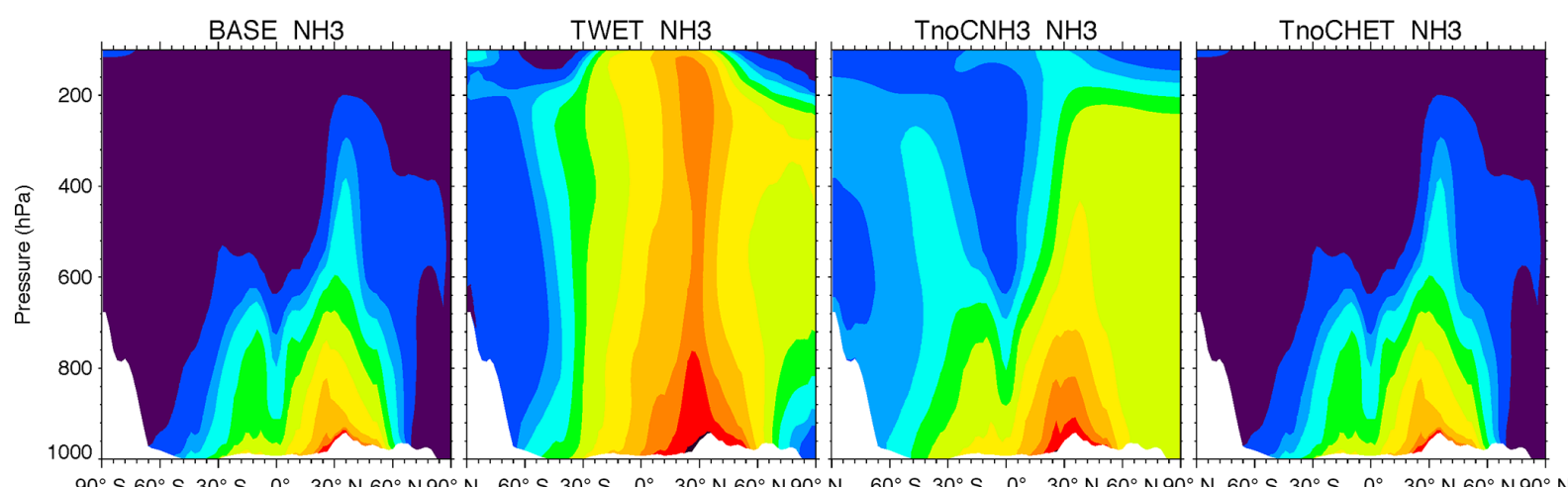

$90^{\circ} \mathrm{S} 60^{\circ} \mathrm{S} 30^{\circ} \mathrm{S} 0^{\circ} 30^{\circ} \mathrm{N} 60^{\circ} \mathrm{N} 90^{\circ} \mathrm{N} 60^{\circ} \mathrm{S} 30^{\circ} \mathrm{S} \quad 0^{\circ} 30^{\circ} \mathrm{N} 60^{\circ} \mathrm{N} 90^{\circ} \mathrm{N} \quad 60^{\circ} \mathrm{S} 30^{\circ} \mathrm{S} 0^{\circ} 30^{\circ} \mathrm{N} 60^{\circ} \mathrm{N} 90^{\circ} \mathrm{N} 60^{\circ} \mathrm{S} 30^{\circ} \mathrm{S} 0^{\circ} 30^{\circ} \mathrm{N} 60^{\circ} \mathrm{N} 90^{\circ} \mathrm{N}$
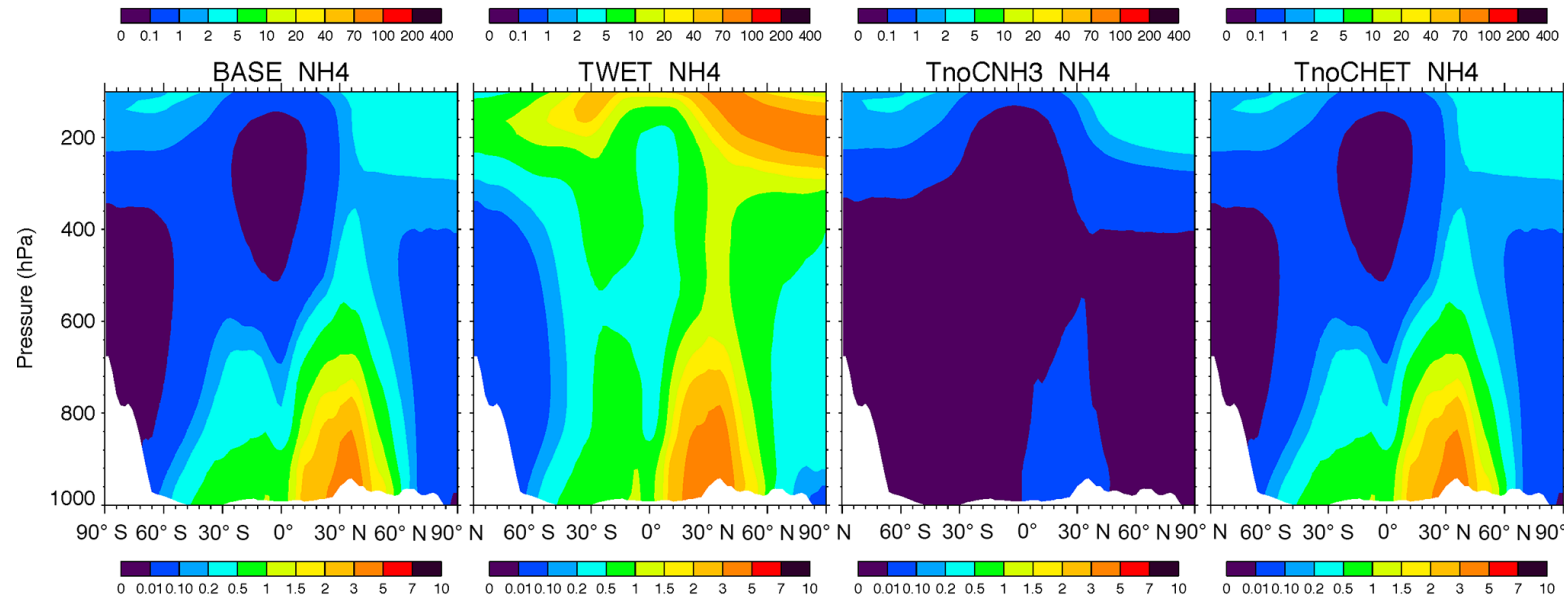

TWET NH4

$\mathrm{TnOCNH} 3 \mathrm{NH} 4$

TnOCHET NH4
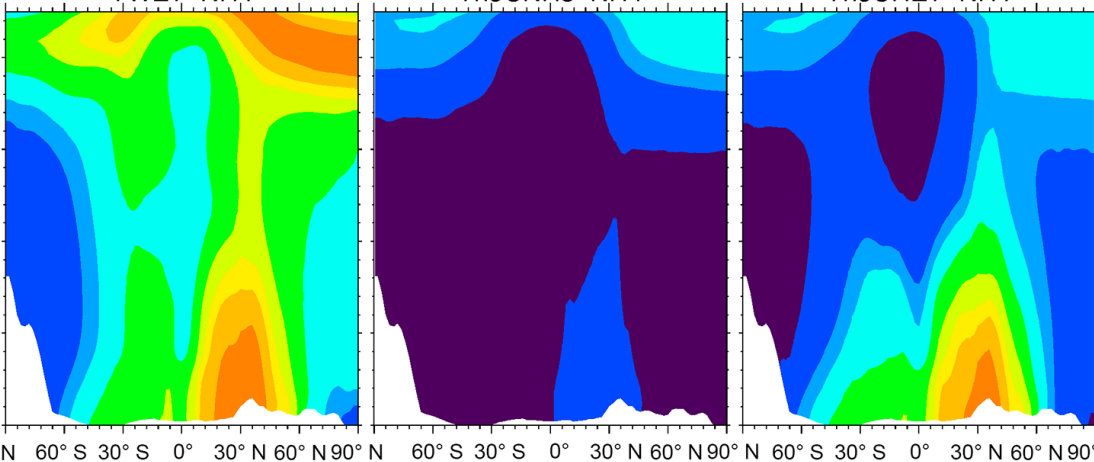

$60^{\circ} \mathrm{S} 30^{\circ} \mathrm{S} 0^{\circ} 30^{\circ} \mathrm{N} 60^{\circ} \mathrm{N} 90^{\circ} \mathrm{N} 60^{\circ} \mathrm{S} 30^{\circ} \mathrm{S} 0^{\circ} 30^{\circ} \mathrm{N} 60^{\circ} \mathrm{N} 90^{\circ} \mathrm{N}$

BASE NO3
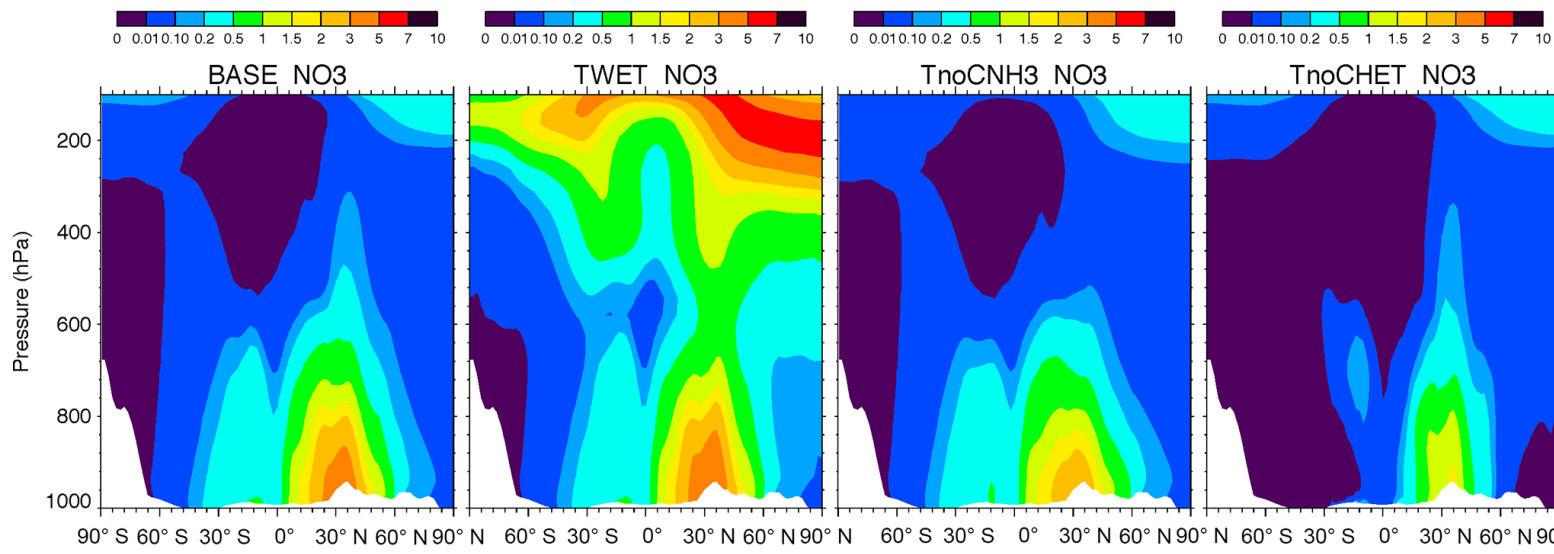

TWET NO3

$\mathrm{TnOCNH} 3 \mathrm{NO} 3$

TnoCHET NO3
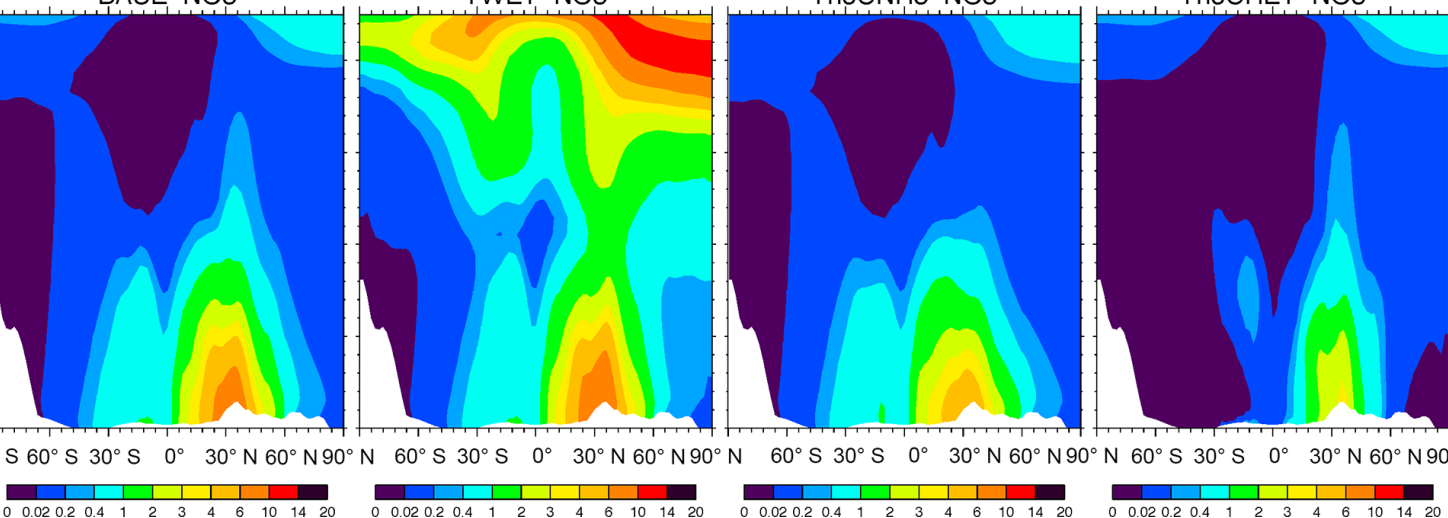

$\mathrm{N} 60^{\circ} \mathrm{S} 30^{\circ} \mathrm{S} 0^{\circ} 30^{\circ} \mathrm{N} 60^{\circ} \mathrm{N} 90^{\circ} \mathrm{N} 60^{\circ} \mathrm{S} 30^{\circ} \mathrm{S} \quad 0^{\circ} 30^{\circ} \mathrm{N} 60^{\circ} \mathrm{N} 90^{\circ} \mathrm{N}$

Figure 8. Zonal mean vertical distribution of $\mathrm{NH}_{3}(0.01 \mathrm{ppb}), \mathrm{NH}_{4}^{+}\left(0.1 \mu \mathrm{g} \mathrm{kg}^{-1}\right)$, and $\mathrm{NO}_{3}^{-}\left(0.05 \mu \mathrm{g} \mathrm{kg}{ }^{-1}\right)$ from the baseline simulation and three sensitivity experiments explained in Table 6.

as well. There is a dramatic decrease (from 17.5 to $1.1 \mathrm{Tg}$ ) in $\mathrm{NH}_{3}$ wet deposition when using pure water $\mathrm{NH}_{3}$ Henry's law constant. Consequently, $\mathrm{NH}_{3}$ will remain in the atmosphere (i.e., $\sim 8$ times more atmospheric $\mathrm{NH}_{3}$ ) to produce $\sim 1.6$ times more $\mathrm{NH}_{4}^{+}$chemically. This, in turn, greatly increases atmospheric $\mathrm{NO}_{3}^{-}$to $0.97 \mathrm{Tg}$ from $0.26 \mathrm{Tg}$ reported in baseline simulation. A large portion of the increased $\mathrm{NH}_{3}$, $\mathrm{NH}_{4}^{+}$, and $\mathrm{NO}_{3}^{-}$resides in the upper troposphere and close to the tropopause region, while the changes of the tracers in the lower troposphere are relatively small, as shown in Fig. 8.
These accumulations at high altitudes are far above (i.e., $\sim 50$ times for $\mathrm{NH}_{4}^{+}$and $\mathrm{NO}_{3}^{-}$) the ARCTAS observed tracer amounts as shown in Fig. 9. The TWET experiment might be an explanation of $\mathrm{NH}_{4}^{+}$and $\mathrm{NO}_{3}^{-}$accumulations near the tropopause region (Fig. 3a-b) in the INCA model whose $\mathrm{NH}_{3}$ Henry's law constant $H^{\Theta}$ is 74 without $\mathrm{pH}$ correction (i.e., a $L^{\Theta}$ model, Table 5). However, it is puzzling that the $\mathrm{NH}_{3}$ simulations by GISS-MATRIX and GISS-OMA, which are the models with $L^{\Theta}$, are closer to the simulations of the models with $H^{\Theta}$, i.e., no $\mathrm{NH}_{4}^{+}$and $\mathrm{NO}_{3}^{-}$accumulation near 


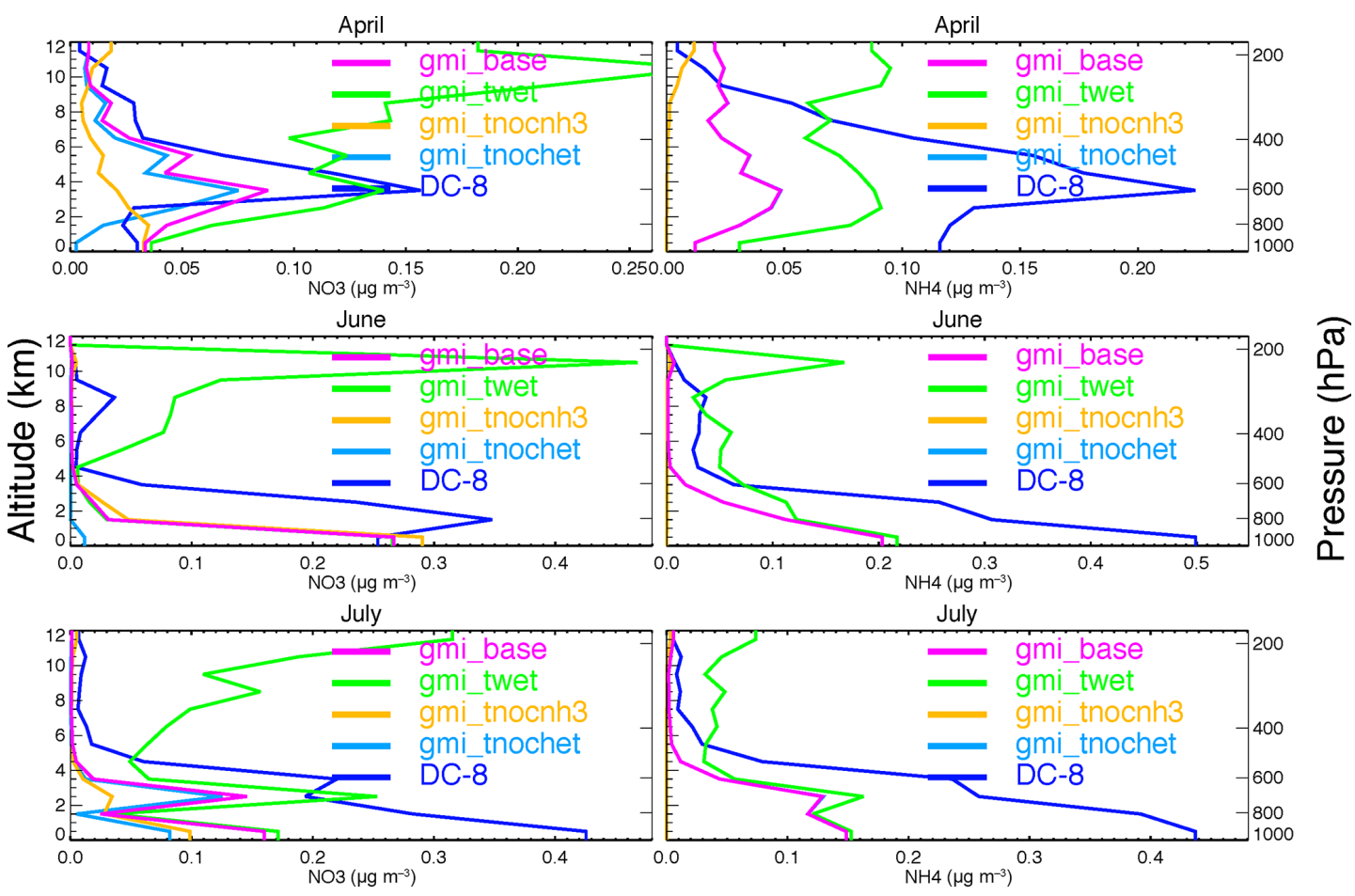

Figure 9. Comparison between GMI simulations and ARCTAS measurements of $\mathrm{NH}_{4}^{+}$and $\mathrm{NO}_{3}^{-}$from the baseline simulation and three sensitivity experiments explained in Table 6 . Note that the light blue line for $\left[\mathrm{NH}_{4}^{+}\right]$is frequently underneath the peak line.

Table 5. Effective Henry's law constant used in the models.

\begin{tabular}{lrr}
\hline $\begin{array}{l}\text { AeroCom } \\
\text { model }\end{array}$ & $\begin{array}{r}H^{\Theta *} \\
\left(\mathrm{M} \mathrm{atm}^{-1}\right)\end{array}$ & $\begin{array}{r}-\Delta H_{\mathrm{sol}} / R \\
(\mathrm{~K})\end{array}$ \\
\hline CHASER & $3 \times 10^{5}$ & 3400 \\
EMAC $^{\mathrm{a}}$ & - & - \\
EMEP $^{\mathrm{b}}$ & - & - \\
GISS-MATRIX & $1 \times 10^{2}$ & 3415 \\
GISS-OMA & $1 \times 10^{2}$ & 3415 \\
GMI & $1.05 \times 10^{6}$ & 4200 \\
INCA & $7.4 \times 10^{1}$ & 3400 \\
OsloCTM2 & $3.3 \times 10^{6}$ & 0 \\
OsloCTM3 & $3.3 \times 10^{6}$ & 0 \\
\hline
\end{tabular}

a EMAC: see its wet deposition description in Sect. 4.1.1 b EMEP: the model does not use Henry's law constant but applies a simple empirical scavenging ratio, which for $\mathrm{NH}_{3}$ is $1.4 \mathrm{e} 6$ for in-cloud and $0.5 \mathrm{e} 6$ for below-cloud scavenging. The scavenging ratio by definition is the ratio of the concentration of a certain pollutant in precipitation to the concentration of the pollutant in the air.

the tropopause and comparable removal of $\mathrm{NH}_{4}^{+}$(Fig. 3a-b and Table 4b).

\subsection{Contribution of dust and sea salt on nitrate formation}

In the presence of acidic accumulation-mode sulfuric acidcontaining aerosols, $\mathrm{HNO}_{3}, \mathrm{NO}_{3}$ radicals, and $\mathrm{N}_{2} \mathrm{O}_{5}$ will deposit on larger alkaline mineral or salt particles (Dentener et al., 1996; Gard et al., 1998; Hauglustaine et al., 2014; Karydis et al., 2016; Murphy and Thomson, 1997; Paulot et al., 2016). Considerable evidence shows that the majority of atmospheric nitrate is formed via reactions associated with dust and sea salt (Allen et al., 2015; Itahashi et al., 2016; Karydis et al., 2016). Coarse-mode nitrate overwhelmingly dominates over remote oceanic regions (Itahashi et al., 2016). Over wide land regions, nitrate also quite often exists in the form of supermicron $\mathrm{NO}_{3}^{-}$balanced by the presence of mineral cations arising from transport of crustal dust and sea spray aerosol (Allen et al., 2015; Lefer and Talbot, 2001).

Investigation of nitrate interactions with mineral dust and sea salt depends on the simulation approach adopted in a model. The traditional equilibrium approach to partition semi-volatile $\mathrm{HNO}_{3}$ between the gas and aerosol phases is no longer possible since the time to reach equilibrium on coarse-mode particles (several hours to days) is typically much longer than the chemical time step used in a global model (less than $1 \mathrm{~h}$ ) (John et al., 1989; Myhre et al., 2006). Meng and Seinfeld (1996) found that on longer timescales, when $\mathrm{NH}_{3} / \mathrm{HNO}_{3}$ started to condense on larger aerosols, 
Table 6. Baseline and three sensitivity experiments in the GMI model.

\begin{tabular}{lll}
\hline Experiment & Setup & Purpose \\
\hline BASE & Standard simulation as described in Sect. 2.1 & Baseline simulation \\
\hline TWET & $\begin{array}{l}\text { Set } \mathrm{NH}_{3} \text { effective Henry's law constant from } \\
1.05 \times 10^{6}(\mathrm{pH}=5.0) \text { to } 62 \text { (pure water) }\end{array}$ & $\begin{array}{l}\text { Review impact of } \mathrm{NH}_{3} \text { wet } \\
\text { deposition }\end{array}$ \\
\hline TnoNH3 & Turn off $\mathrm{NO}_{3}^{-}$production from $\mathrm{NH}_{3} / \mathrm{NH}_{4}^{+}$ & $\begin{array}{l}\text { Identify size/location of the } \mathrm{NO}_{3}^{-} \\
\text {formation from } \mathrm{NH}_{3} / \mathrm{NH}_{4}^{+}\end{array}$ \\
\hline TnoHET & $\begin{array}{l}\text { Turn off } \mathrm{NO}_{3}^{-} \text {production from dust and sea } \\
\text { salt }\end{array}$ & $\begin{array}{l}\text { Identify size/location of the } \mathrm{NO}_{3}^{-} \\
\text {formation from dust and sea salt }\end{array}$ \\
\hline
\end{tabular}

Table 7. $\mathrm{NO}_{3}^{-}, \mathrm{NH}_{4}^{+}, \mathrm{NH}_{3}$ and $\mathrm{HNO}_{3}$ budgets from the base simulation and three sensitivity experiments.

\begin{tabular}{|c|c|c|c|c|c|c|c|c|}
\hline Tracer & Experiment & $\begin{array}{r}\text { Burden } \\
(\mathrm{Tg})\end{array}$ & $\begin{array}{r}\text { SConc } \\
\left(\mu \mathrm{g} \mathrm{kg}^{-1}\right)\end{array}$ & $\begin{array}{r}\text { DDep } \\
\left(\mathrm{Tg} \mathrm{a}^{-1}\right)\end{array}$ & $\begin{array}{r}\text { WDep } \\
\left(\mathrm{Tg} \mathrm{a}^{-1}\right)\end{array}$ & $\begin{array}{r}\text { ChemDUSS } \\
\left(\mathrm{Tg} \mathrm{a}^{-1}\right)\end{array}$ & $\begin{array}{l}\text { ChemP } \\
\left(\mathrm{Tg} \mathrm{a}^{-1}\right)\end{array}$ & $\begin{array}{r}\text { Lifetime } \\
\text { (days) }\end{array}$ \\
\hline \multirow{4}{*}{$\mathrm{NO}_{3}^{-}$} & BASE & 0.26 & 0.22 & 14.9 & 31.5 & 41.9 & 4.8 & 2.1 \\
\hline & TWET & 0.97 & 0.23 & 14.8 & 43.3 & 41.0 & 18.3 & 6.0 \\
\hline & TnoNH3 & 0.20 & 0.17 & 14.7 & 27.5 & 42.3 & 0 & 1.7 \\
\hline & TnoHET & 0.099 & 0.065 & 0.61 & 6.70 & 0 & 7.1 & 5.0 \\
\hline Tracer & Experiment & $\begin{array}{r}\text { Emi } \\
\left(\mathrm{Tg} \mathrm{a}^{-1}\right)\end{array}$ & $\begin{array}{r}\text { Burden } \\
(\mathrm{Tg})\end{array}$ & $\begin{array}{r}\text { SConc } \\
\left(\mu \mathrm{g} \mathrm{kg}^{-1}\right)\end{array}$ & $\begin{array}{r}\text { DDep } \\
\left(\mathrm{Tg} \mathrm{a}^{-1}\right)\end{array}$ & $\begin{array}{r}\text { WDep } \\
\left(\mathrm{Tg} \mathrm{a}^{-1}\right)\end{array}$ & $\begin{array}{r}\text { ChemP/L } \\
\left(\mathrm{Tg} \mathrm{a}^{-1}\right)\end{array}$ & $\begin{array}{r}\text { Lifetime } \\
\text { (days) }\end{array}$ \\
\hline \multirow[t]{4}{*}{$\mathrm{NH}_{4}^{+}$} & BASE & & 0.17 & 0.14 & 1.7 & 30.6 & 32.2 & 1.9 \\
\hline & TWET & & 0.48 & 0.16 & 1.9 & 50.7 & 53.0 & 3.4 \\
\hline & TnoNH3 & & - & - & - & - & - & - \\
\hline & TnoHET & & 0.17 & 0.14 & 1.6 & 30.6 & 32.2 & 1.9 \\
\hline \multirow[t]{4}{*}{$\mathrm{NH}_{3}$} & BASE & 60.4 & 0.11 & 0.40 & 12.6 & 17.5 & 30.4 & 0.67 \\
\hline & TWET & & 0.85 & 0.81 & 8.70 & 1.1 & 50.1 & 5.2 \\
\hline & TnoNH3 & & 0.32 & 0.58 & 20.9 & 39.3 & 0 & 1.9 \\
\hline & TnoHET & & 0.10 & 0.40 & 12.6 & 17.4 & 30.4 & 1.2 \\
\hline
\end{tabular}

their gas phase concentrations decreased so that some of the condensed matter could be driven back to the gas phase from the small semi-volatile aerosols. A fix to a non-equilibrium state would be to implement a kinetic formulation for the particles that have a long equilibrium timescale (Feng and Penner, 2007; Karydis et al., 2010). However, implementing explicit kinetics in a global model would be computationally expensive and hence is not feasible for long-term climate simulations. Several approximations have been developed to allow computational efficiency, although they might compromise model accuracy.

Four such approaches are adopted by the nine models participating in this study: (1) using equilibrium calculations for fine-mode particles only while neglecting nitrate formation on coarse-mode particles (CHASER and GISSMATRIX); (2) combining equilibrium calculation for a solution of $\mathrm{SO}_{4}^{2-}-\mathrm{NO}_{3}^{-}-\mathrm{NH}_{4}^{+}-\mathrm{H}_{2} \mathrm{O}$ and heterogeneous reaction calculation for nitrogen uptake on dust and sea salt using a first-order loss rate (EMEP, GMI, GISS-OMA, and INCA); (3) running an equilibrium model including $\mathrm{NH}_{3}$, dust, and sea salt repeatedly for aerosol sizes from fine mode to coarse mode (OsloCTM2 and OsloCTM3); and (4) using only the fraction of the gas that can kinetically condense within the time step of the model in the equilibrium calculations for each aerosol size mode (EMAC).

Nitrate is formed primarily on dust and sea salt by GMI $(88 \%)$ and INCA $(82 \%)$ (see Table $4 a)$. INCA further separates the formation as $45 \%$ on dust and $37 \%$ on sea salt. Unfortunately, the other models are missing a detailed nitrate chemistry budget report. A potential impact of dust and sea salt on nitrate formation, nevertheless, can be inferred from the approach adopted by a model. For example, approach 1 (mentioned above) is problematic due to the absence of coarse-mode nitrate, an important portion of nitrate, which results in relatively low nitrate burdens for CHASER and GISS-MATRIX. OsloCTM2 and OsloCTM3 adopt approach 3 . Although the two models allow fine-mode particles to reach equilibrium first, the subsequent equilibrium calculation for coarse-mode particles may still produce coarse-mode nitrate too quickly; see discussion of the ra- 
tio of coarse-mode nitrate in the next subsection. To avoid such overestimations on the production of coarse-mode nitrate, EMAC allows only a fraction of $\mathrm{HNO}_{3}$ to partition in the aerosol phase by assuming diffusion-limited condensation (Pringle et al., 2010).

To further understand the role of homogeneous and heterogeneous chemical reaction processes in nitrate formation, we conducted two more sensitivity experiments, TnoCNH3 and TnoCHET, with the GMI model (Table 6). Experiment TnoCNH3 turned off chemical conversion of $\mathrm{NH}_{3}$ to $\mathrm{NH}_{4}^{+}$ in the GMI thermodynamic equilibrium model, while experiment TnoCHET excluded the nitrate formation via heterogeneous reaction of gas $\mathrm{HNO}_{3}$ on the particles of dust and sea salt. The budget report, vertical zonal mean distribution, and model-observation comparison of $\mathrm{NH}_{3}, \mathrm{NH}_{4}^{+}$, and $\mathrm{NO}_{3}^{-}$are given in Table 7 and Figs. 8-9, respectively. It is not surprising that experiment TnoCNH3 gives a higher atmospheric $\mathrm{NH}_{3}$ burden $(0.32 \mathrm{Tg})$ compared to baseline $(0.11 \mathrm{Tg})$ with little $\mathrm{NH}_{4}^{+}$left (from its initial field). The interesting finding is that the formed $\mathrm{NO}_{3}^{-}$has only slightly decreased compared to baseline (from 0.26 to $0.20 \mathrm{Tg}$ ), confirming the importance of $\mathrm{NO}_{3}^{-}$formation via dust and sea salt. For the TnoCHET experiment, the simulations of $\mathrm{NH}_{3}$ and $\mathrm{NH}_{4}^{+}$stay the same but the formed $\mathrm{NO}_{3}^{-}$is decreased dramatically (from 0.26 to 0.10 ), indicating that $\mathrm{NO}_{3}^{-}$formation via $\mathrm{NH}_{3}$ chemistry alone in the GMI model is relatively small. The chemical production of $\mathrm{NO}_{3}^{-}$is about 6 times larger in TnoCNH3 (via dust and sea salt) than in TnoCHET (via $\mathrm{NH}_{3}$ ). However, the $\mathrm{NO}_{3}^{-}$produced via $\mathrm{NH}_{3}$ chemistry (TnoCHET) is nonnegligible over remote regions impacted by long-range transport, as shown in the analysis of April Alaska observations in Fig. 9.

\subsection{Nitrate size distribution}

Unlike sulfate aerosol, a noticeable fraction of nitrate aerosol is in coarse mode. Coarse-mode aerosol nitrate is formed due to presence of dust and/or sea salt. In other words, the formation of nitrate on coarse-mode dust and sea salt particles is the major factor controlling size distribution. Other factors, such as $\mathrm{NH}_{3} / \mathrm{NH}_{4}^{+} / \mathrm{NO}_{3}^{-}$chemistry and atmospheric transport and removal processes, also affect nitrate size distribution. Having an accurate aerosol size distribution is critical in climate forcing estimations, since large size particles have a relatively small optical cross section at a given aerosol mass loading, and the nitrate material coating on dust particles has almost no direct impact on the dust optics, although it greatly impacts dust lifetime (Bauer et al., 2007). Given that the deposition velocity of a coarse particle is greater than that of a fine particle, an accurate size distribution is also necessary to estimate deposition of particulate nitrates (Yeatman et al., 2001; Sadanaga et al., 2008). This estimation is particularly important over oceans where coarse-mode nitrate dominates (Itahashi et al., 2016) and nitrogen supply is often in deficit (Hansell and Follows, 2008).

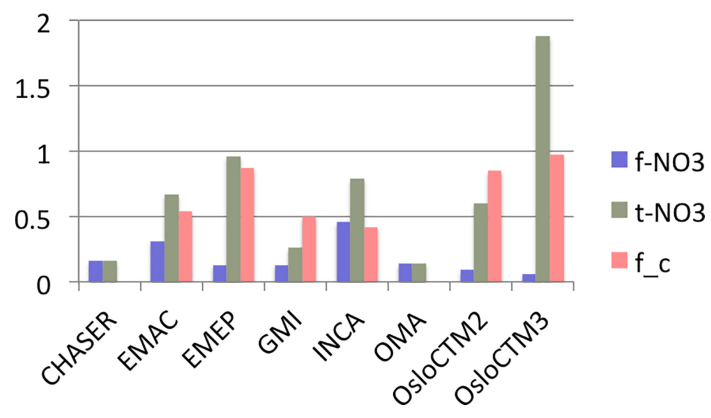

Figure 10. $\mathrm{NO}_{3}^{-}$fine-mode burden (f- $\mathrm{NO}_{3}, \mathrm{Tg}$ ), total burden (t$\mathrm{NO}_{3}, \mathrm{Tg}$ ), and coarse-mode fraction (f_c) for the eight AeroCom models.

As we have discussed in Sect. 5.2, nitrate size distribution varies with the approaches adopted for nitrate formation on coarse-mode aerosols (i.e., dust and sea salt). Figure 10 gives the burdens of nitrate in fine-mode and coarsemode portions and the ratio between coarse mode and total (f_c) for the eight discussed models. The ratio ranges from $0 \%$ (CHASER and GISS-OMA) to $\sim 50 \%$ (EMAC, GMI, and INCA), 80\% (EMEP and OsloCTM2), and $97 \%$ (OsloCTM3). The two OsloCTMs give the highest f_c partially because they run TEQM model for coarse-mode particles.

A wide range of $\mathrm{f} \_\mathrm{c}$, from 0 to $>90 \%$, has been reported previously by model simulations (Adams et al., 2001; Bauer et al., 2007; Jacobson 2001), while the range is narrowed down to $40-60 \%$ for the model studies using the approach that solves the dynamic mass transfer equation for coarsemode particles (Feng and Penner, 2007; Xu and Penner, 2012).

It is worth pointing out that aerosol microphysics modify aerosol size as well. For example, a process like coagulation would also allow $\mathrm{NO}_{3}^{-}$to mix with other particles and enter coarse-mode aerosol. New particle formation/nucleation would add $\mathrm{NH}_{3} / \mathrm{NH}_{4}^{+} / \mathrm{NO}_{3}^{-}$into the ultra-fine mode. Except EMAC and GISS-MATRIX, the majority of models involved in this study are bulk aerosol models that do not account for aerosol microphysics.

It is challenging to verify the nitrate size distribution globally due to the limited measurements of time and space. Measurements over regional and station sites indicated that the ratio of f_c could be very high and vary seasonally over oceanic sites. For example, annual mean f_c during 2002-2004 from the Fukue supersite observatory is about $72 \%$ with a seasonal variation of $60-80 \%$ in winter and of around $80 \%$ in summer (Itahashi et al., 2016).

However, the ratio could be varied dramatically over land or the areas affected by land pollution. For example, observations of fine and coarse particulate nitrate at several rural locations in the United States indicated that nitrate was predominantly in submicron ammonium nitrate particles during the Bondville and San Gorgonio (April) campaigns, in 
coarse-mode nitrate particles at the Grand Canyon (May) and Great Smoky Mountains (July/August), and both fine- and coarse-mode nitrate during the studies at Brigantine and San Gorgonio (July) (Lee et al., 2008). Allen et al. (2015) examined aerosol composition data collected during the summer 2013 SOAS and concluded that inorganic nitrate in the southeastern US likely exists in the form of supermicron $\mathrm{NO}_{3}^{-}$, balanced by the presence of mineral cations arising from the transport of crustal dust and sea spray aerosol. The measurements over Harvard Forest, a rural site in central Massachusetts, supported the majority of nitrate mass being associated with water-soluble supermicron soil-derived $\mathrm{Ca}^{2+}$ in an acidic environment (Lefer and Talbot, 2001). Measurements taken in Paris during the ESQUIF campaign found that the coarse nitrate fraction represents up to $60 \%$ of total particulate nitrate mass at night and $80 \%$ during the day (Hodzic et al., 2006a, b). Measurements of coarse-mode aerosol nitrate and ammonium at two polluted coastal sites, Weybourne, England, and Mace Head, Ireland, during polluted flow when the air had passed over strong source regions of the UK and northern Europe, showed 40-60\% of the nitrate was found in particles with diameter $>1 \mu \mathrm{m}$, but under clean marine conditions almost $100 \%$ conversion was seen (Yeatman et al., 2001).

\section{Conclusions}

We present the AeroCom phase III nitrate study by assessing aerosol simulations of nitrate and ammonium and their precursors with nine global models. Five of the models couple the chemical calculation online with meteorological simulation, and four use archived meteorological fields driving chemistry. To focus on chemical-physical processes behind the diversity of nitrate simulation, all participating models are encouraged to use the HTAP2 emission inventory for aerosol and gas emissions from anthropogenic, aircraft, and ship sources. The simulated aerosols of nitrate and ammonium and their precursors are compared among the models and evaluated against various measurements including surface concentrations and dry/wet depositions from surface measurements, and vertical distributions from aircraft measurements.

All models capture the main features of the distribution of nitrate and ammonium: large surface and column amounts over China, south Asia, Europe, and the US. These regions are typically densely populated with large $\mathrm{NH}_{3}$ and $\mathrm{NO}_{x}$ emissions. Many models also show enhanced nitrate and ammonium over the Middle East and the continents of South America, Africa, and Australia over the Southern Hemisphere. The former undergoes huge dust pollution and the latter experiences fires that emit both $\mathrm{NH}_{3}$ and $\mathrm{NO}_{x}$.

The diversity of nitrate and ammonium simulations among the models is large: the ratio of the maximum to minimum quantities among the nine models is 13.4 and 4.4 for model- simulated global mass burdens of nitrate and ammonium, respectively, and 3.9 and 5.2 for the corresponding lifetimes. These values are also larger than those of sulfate: 4.0 for global burden and 3.0 for lifetime. The agreement between models and observations is better for aerosol components than for gas tracers. All models underestimate $\mathrm{NH}_{3}$ surface mass concentrations but most models overestimate surface $\mathrm{HNO}_{3}$ concentrations over North America and east Asia. Performance of $\mathrm{NH}_{3}$ is the worst: this could partially be associated with its relatively lower measurement accuracy, i.e., a loss of ammonia possibly on the filters designed to collect $\mathrm{NH}_{3}$ (Williams et al., 1992). Among aerosol simulations, model performance based on evaluation of surface mixing ratio and dry/wet depositions is very similar for $\mathrm{NH}_{4}^{+}$and $\mathrm{SO}_{4}^{2-}$, while slightly worse for $\mathrm{NO}_{3}^{-}$. Models severely underestimate the aerosol concentrations with only a few exceptions when compared with aircraft measurements and this problem is worse over regions impacted by long-range transport than those closer to sources.

There are many intrinsic reasons for a larger diversity in nitrate simulations among models. Nitrate is involved in much more complicated chemistry: the chemical mechanism needs to handle a multi-phase, multi-component solution system. The system sometimes cannot even be solved using the thermodynamic equilibrium approach when coarsemode dust and sea salt particles are present. A reasonable nitrate simulation also depends on good simulations of various precursors, such as $\mathrm{NH}_{3}, \mathrm{HNO}_{3}$, dust, and sea salt, although models account for the impact of dust and sea salt very differently. Even an accurate simulation of $\mathrm{SO}_{4}^{2-}$ is a prerequisite because $\mathrm{SO}_{4}^{2-}$ surpasses $\mathrm{NO}_{3}^{-}$when reacting with $\mathrm{NH}_{4}^{+}$.

The models' intercomparison and model-observation comparison revealed at least two critical issues in nitrate simulation that demand further exploration: $\mathrm{NH}_{3}$ wet deposition and relative contribution to $\mathrm{NO}_{3}^{-}$formation via $\mathrm{NH}_{3}$ and dust/sea salt. The nine participating models adopt very different effective Henry's law constants for $\mathrm{NH}_{3}$, with one group having a value equal or less than 100 (in pure water) and the other larger than $1 \times 10^{5}$ (with $\mathrm{pH}$ correction). Sensitivity studies using the GMI model indicated that without $\mathrm{pH}$ correction, $\mathrm{NH}_{3}$ wet deposition decreases massively (from 17.5 to $1.1 \mathrm{Tg}$ ), which prolongs atmospheric $\mathrm{NH}_{3}$ lifetime (from 0.67 to 5.2 days) and enhances its atmospheric burden (from 0.11 to $0.85 \mathrm{Tg}$ ) and thus the atmospheric burden of $\mathrm{NH}_{4}^{+}$(from 0.17 to $0.48 \mathrm{Tg}$ ) and $\mathrm{NO}_{3}^{-}$(from 0.26 to $0.97 \mathrm{Tg}$ ) as well. These enhanced tracers tend to accumulate in the upper troposphere and close to the tropopause and are too high when compared to aircraft measurements. Since liquid phase reaction (AR2) in the Appendix can reach equilibrium quickly within a chemical time step, we recommend including it in accounting for the $\mathrm{NH}_{3}$ solution. Theoretically, a more accurate approach is to combine wet removal with liquid phase chemistry calculation. In other words, instead of using an implicit calculation of effective Henry's law con- 
stant, the gas-liquid phase equilibrium is explicitly calculated based on the chemical mechanism used in the liquid phase. The solution of $\mathrm{NH}_{3}$ is calculated by solving a set of partial differential equations, which includes not only the gas-liquid phase equilibrium but also all the important reactions in the liquid phase, as adopted in EMAC model.

All the models use thermodynamic equilibrium to solve the chemical process of $\mathrm{NH}_{3} / \mathrm{NH}_{4}^{+}$to $\mathrm{NO}_{3}^{-}$formation in finemode aerosols. However, the models adopt very different ways in accounting for the contribution of these reactions on the surface of dust and sea salt particles: some account for both dust and sea salt, some account for only dust or only sea salt, and two models do not even account for dust and sea salt. The methodologies that take dust and sea salt into account are also very different, i.e., together with $\mathrm{NH}_{4}^{+}$using the thermodynamic equilibrium model or simply adopting a first-order loss rate on dust and sea salt surfaces. The chemical budget reported by GMI and INCA indicates that the majority $(>80 \%)$ of global $\mathrm{NO}_{3}^{-}$formation is via reaction on dust and sea salt. Two sensitivity experiments using the GMI model by tagging the $\mathrm{NO}_{3}^{-}$formation from either $\mathrm{NH}_{3} / \mathrm{NH}_{4}^{+}$chemistry or heterogeneous reactions on dust and sea salt confirm the critical importance of the latter process and indicate that the former process is relatively important in remote regions. The importance of $\mathrm{NO}_{3}^{-}$formation on dust and sea salt lies also in its determination on nitrate particle size distribution, so that has an implication in air quality and climate studies as well.

Our work presents a first effort to assess nitrate simulation from chemical (e.g., chemistry among $\mathrm{NH}_{3}, \mathrm{NH}_{4}^{+}$, $\mathrm{NO}_{3}^{-}, \mathrm{SO}_{4}^{2-}$, dust, and sea salt) and physical processes (e.g., emission, dry deposition, and wet deposition). A companion study is proposed by the AeroCom phase III nitrate activity to investigate how sensitive nitrate formation is in response to possible future changes in emission and meteorological fields. These perturbation fields include increasing $\mathrm{NH}_{3}$ emission, decreasing $\mathrm{NO}_{x}, \mathrm{SO}_{x}$, and dust emissions, and in- creasing atmospheric temperature and relative humidity. It would be particularly interesting to examine how aerosol $\mathrm{pH}$ changes and its influence on the atmospheric acid/base gas-particle system. Future aerosol pH does not necessarily increase with $\mathrm{SO}_{2}$ emission reduction. Indeed, studies over the southeast US indicated that its aerosol has become more acidic over the past decade although $\mathrm{SO}_{2}$ emission decreased and $\mathrm{NH}_{3}$ emission stayed constant (Silvern et al., 2017; Weber et al., 2016). This environment of high aerosol acidity hinders the formation of nitrate aerosol, which only occurs when $\mathrm{pH}$ is over $\sim 2$ to 3 (Weber et al., 2016). In addition, understanding why and how the system is insensitive to changing $\mathrm{SO}_{2}$ levels due to buffering of the partitioning of semivolatile $\mathrm{NH}_{3}$ helps us to gain insight on how errors in sulfate (and ammonium) may propagate to errors in aerosol nitrate. In particular, the correlation between model predictions and observations for $\mathrm{SO}_{4}^{2-}$ and $\mathrm{NH}_{4}^{+}$is quite poor for some models (Fig. 4). It would also be interesting to include organic gas/aerosol in the system since they are not only important atmospheric components but also reduce the uptake of $\mathrm{NH}_{3}$. Competition for uptake between $\mathrm{NH}_{3}$ and organic gases considerably slows down the approach to thermodynamic equilibrium (Silvern et al., 2017). Based on the findings of this work, modelers should pay particular attention to incorporating dust and sea salt and treating $\mathrm{NH}_{3}$ wet deposition to improve nitrate simulation. Further evaluation using satellite measurements, such as $\mathrm{NH}_{3}$ products from IASI and TES, is desired and will be conducted. Such evaluation requires global three-dimensional high-frequency model data. Potential future study also includes estimation of nitrate forcing for climate change.

Data availability. All model data can be downloaded from the AeroCom database by contacting Michael Schulz (michael.schulz@met.no). All measurement data are publicly available. 


\section{Appendix A}

For some acidic/basic gases, including $\mathrm{NH}_{3}$, Henry's law constant is also a function of $\mathrm{pH}$ in water (also known as effective Henry's law constant). For this reason, not only does the aqueous chemistry reaction $\mathrm{NH}_{3}+\mathrm{H}_{2} \mathrm{O}$ (Reaction AR1) reach equilibrium within a chemical time step but its product $\mathrm{NH}_{3} \cdot \mathrm{H}_{2} \mathrm{O}$ (Reaction AR2) does as well.

$\mathrm{NH}_{3}+\mathrm{H}_{2} \mathrm{O} \Leftrightarrow \mathrm{NH}_{3} \cdot \mathrm{H}_{2} \mathrm{O}$

$\mathrm{NH}_{3} \cdot \mathrm{H}_{2} \mathrm{O} \Leftrightarrow \mathrm{NH}_{4}^{+}+\mathrm{OH}^{-}$.

Here, $\mathrm{NH}_{4}^{+}$is the ammonium ion and $\mathrm{OH}^{-}$is the hydroxide ion. The total dissolved ammonia $\left[\mathrm{NH}_{3}^{T}\right]$ is given by

$$
\begin{aligned}
{\left[\mathrm{NH}_{3}{ }^{T}\right] } & =\left[\mathrm{NH}_{3} \cdot \mathrm{H}_{2} \mathrm{O}\right]+\left[\mathrm{NH}_{4}^{+}\right] \\
& =p_{\mathrm{NH}_{3}} H^{\Theta}\left(1+\frac{K_{\mathrm{al}}\left[H^{+}\right]}{K_{\mathrm{W}}}\right) \\
& \approx p_{\mathrm{NH}_{3}}\left(H^{\Theta} \frac{K_{\mathrm{al}}\left[H^{+}\right]}{K_{\mathrm{w}}}\right) .
\end{aligned}
$$

Here, $p_{\mathrm{NH}_{3}}$ is the partial pressure of $\mathrm{NH}_{3}$, $K_{\mathrm{al}}=\left[\mathrm{NH}_{4}^{+}\right]\left[\mathrm{OH}^{-}\right] /\left[\mathrm{NH}_{3} \cdot \mathrm{H}_{2} \mathrm{O}\right] \approx 1.8 \times 10^{-5}, \quad$ and $K_{\mathrm{w}}=1.0 \times 10^{-14}$ at $298 \mathrm{~K}$ in pure water. So the effective Henry's law constant $H^{\Theta *}$ is inferred from $H^{\Theta}$ with a correction of $\mathrm{pH}\left(\mathrm{pH}=-\log _{10}\left[H^{+}\right]\right)$as

$H^{\Theta *}=H^{\Theta} \frac{K_{\mathrm{al}}\left[H^{+}\right]}{K_{\mathrm{w}}}$. 
Competing interests. The authors declare that they have no conflict of interest.

Acknowledgements. The authors thank the editors and two reviewers who helped to improve the paper. The authors also thank the various observational groups (i.e., CASTNET, EMEP, EANET, and ARCTAS) for their quality-controlled field measurements. This work was supported by the NASA MAP program (NNX10AK61G) and the NASA ACMAP program (NNX17AG31G). GM has received support from the Research Council of Norway through project nos. 229796 (AeroCom-P3) and 250573 (SUPER).

Edited by: Alma Hodzic

Reviewed by: two anonymous referees

\section{References}

Adams, P. J., Seinfeld, J. H., Koch, D., Mickley, L. J., and Jacob, D. J.: General circulation model assessment of direct radiative forcing by the sulfate-nitrate-ammonium-water inorganic aerosol system, J. Geophys. Res., 106, 1097-1112, https://doi.org/10.1029/2000JD900512, 2001.

Allen, H. M., Draper, D. C., Ayres, B. R., Ault, A., Bondy, A., Takahama, S., Modini, R. L., Baumann, K., Edgerton, E., Knote, C., Laskin, A., Wang, B., and Fry, J. L.: Influence of crustal dust and sea spray supermicron particle concentrations and acidity on inorganic $\mathrm{NO}_{3}^{-}$aerosol during the 2013 Southern Oxidant and Aerosol Study, Atmos. Chem. Phys., 15, 10669-10685, https://doi.org/10.5194/acp-15-10669-2015, 2015.

Bauer, S. E. and Koch, D.: Impact of heterogeneous sulfate formation at mineral dust surfaces on aerosol loads and radiative forcing in the Goddard Institute for Space Studies general circulation model, J. Geophys. Res., 110, D17202, https://doi.org/10.1029/2005JD005870, 2005.

Bauer, S. E., Balkanski, Y., Schulz, M., Hauglustaine, D. A., and Dentener, F.: Global modeling of heterogeneous chemistry on mineral aerosol surfaces: Influence on tropospheric ozone chemistry and comparison to observations, J. Geophys. Res.-Atmos., 109, D02304, https://doi.org/10.1029/2003jd003868, 2004.

Bauer, S. E., Koch, D., Unger, N., Metzger, S. M., Shindell, D. T., and Streets, D. G.: Nitrate aerosols today and in 2030: a global simulation including aerosols and tropospheric ozone, Atmos. Chem. Phys., 7, 5043-5059, https://doi.org/10.5194/acp-7-50432007, 2007.

Bauer, S. E., Wright, D. L., Koch, D., Lewis, E. R., McGraw, R., Chang, L.-S., Schwartz, S. E., and Ruedy, R.: MATRIX (Multiconfiguration Aerosol TRacker of mIXing state): an aerosol microphysical module for global atmospheric models, Atmos. Chem. Phys., 8, 6003-6035, https://doi.org/10.5194/acp-8-60032008, 2008.

Bauer, S. E., Tsigaridis, K., and Miller, R.: Significant atmospheric aerosol pollution caused by world food cultivation, Geophys. Res. Lett., 43, 5394-5400, https://doi.org/10.1002/2016GL068354, 2016.

Bellouin, N., Rae, J., Jones, A., Johnson, C., Haywood, J., and Boucher, O.: Aerosol forcing in the Climate Model Intercomparison Project (CMIP5) simulations by HadGEM2-ES and the role of ammonium nitrate, J. Geophys. Res.-Atmos., 116, D20206, https://doi.org/10.1029/2011jd016074, 2011.

Berntsen, T. K. and Isaksen, I. S. A.: A global three-dimensional chemical transport model for the troposphere. 1. Model description and CO and ozone results, J. Geophys. Res.-Atmos., 102, 21239-21280, 1997.

Bessagnet, B. and Rouil, L.: Feedback on and analysis of the PM pollution episode in March 2014, presentation at 19-th EIONET Workshop on Air Quality Assessment and Management, 30 September-1 October 2014, Berne, Switzerland, 2014.

Bian, H. and Zender, C. S.: Mineral dust and global tropospheric chemistry: The relative roles of photolysis and heterogeneous uptake, J. Geophys. Res., 108, 4672, https://doi.org/10.1029/2002JD003143, 2003.

Bian, H., Chin, M., Rodriguez, J. M., Yu, H., Penner, J. E., and Strahan, S.: Sensitivity of aerosol optical thickness and aerosol direct radiative effect to relative humidity, Atmos. Chem. Phys., 9, 2375-2386, https://doi.org/10.5194/acp-9-2375-2009, 2009.

Bian, H., Colarco, P. R., Chin, M., Chen, G., Rodriguez, J. M., Liang, Q., Blake, D., Chu, D. A., da Silva, A., Darmenov, A. S., Diskin, G., Fuelberg, H. E., Huey, G., Kondo, Y., Nielsen, J. E., Pan, X., and Wisthaler, A.: Source attributions of pollution to the Western Arctic during the NASA ARCTAS field campaign, Atmos. Chem. Phys., 13, 4707-4721, https://doi.org/10.5194/acp13-4707-2013, 2013.

Bouwman, A. F., Lee, D. S., Asman, W. A. H., Dentener, F. J., Van Der Hoek, K. W., and Olivier, J. G. J.: A Global High-Resolution Emission Inventory for Ammonia, Global Biogeochem. Cy., 11, 561-587, 1997.

Cubison, M. J., Ortega, A. M., Hayes, P. L., Farmer, D. K., Day, D., Lechner, M. J., Brune, W. H., Apel, E., Diskin, G. S., Fisher, J. A., Fuelberg, H. E., Hecobian, A., Knapp, D. J., Mikoviny, T., Riemer, D., Sachse, G. W., Sessions, W., Weber, R. J., Weinheimer, A. J., Wisthaler, A., and Jimenez, J. L.: Effects of aging on organic aerosol from open biomass burning smoke in aircraft and laboratory studies, Atmos. Chem. Phys., 11, 12049-12064, https://doi.org/10.5194/acp-11-12049-2011, 2011.

Davis, J. M., Bhave, P. V., and Foley, K. M.: Parameterization of $\mathrm{N}_{2} \mathrm{O}_{5}$ reaction probabilities on the surface of particles containing ammonium, sulfate, and nitrate, Atmos. Chem. Phys., 8, 52955311, https://doi.org/10.5194/acp-8-5295-2008, 2008.

DeCarlo, P. F., Kimmel, J. R., Trimborn, A., Northway, M. J., Jayne, J. T., Aiken, A. C., Gonin, M., Fuhrer, K., Horvath, T., Docherty, K. S., Worsnop, D. R., and Jimenez, J. L.: Field-deployable, high-resolution, time-of-flight aerosol mass spectrometer, Anal. Chem., 78, 8281-8289, 2006.

Dentener, F. and Crutzen, P.: Reaction of NO on Tropospheric Aerosols: Impact on the Global Distributions of NO, O, and OH, J. Geophys. Res., 98, 7149-7163, https://doi.org/10.1029/92JD02979, 1993.

Dentener, F., Kinne, S., Bond, T., Boucher, O., Cofala, J., Generoso, S., Ginoux, P., Gong, S., Hoelzemann, J. J., Ito, A., Marelli, L., Penner, J. E., Putaud, J.-P., Textor, C., Schulz, M., van der Werf, G. R., and Wilson, J.: Emissions of primary aerosol and precursor gases in the years 2000 and 1750 prescribed data-sets for AeroCom, Atmos. Chem. Phys., 6, 43214344, https://doi.org/10.5194/acp-6-4321-2006, 2006. 
Dentener, F. J., Carmichael, G. R., Zhang, Y., Lelieveld, J., and Crutzen, P. J.: Role of mineral aerosol as a reactive surface in the global troposphere, J. Geophys. Res, 101, 22869-22889, 1996.

Ensberg, J. J., Craven, J. S., Metcalf, A. R., Allan, J. D., Angevine, W. M., Bahreini, R., Brioude, J., Cai, C., Coe, H., de Gouw, J. A., Ellis, R. A., Flynn, J. H., Haman, C. L., Hayes, P. L., Jimenez, J. L., Lefer, B. L., Middlebrook, A. M., Murphy, J. G., Neuman, J. A., Nowak, J. B., Roberts, J. M., Stutz, J., Taylor, J. W., Veres, P. R., Walker, J. M., and Seinfeld, J. H.: Inorganic and black carbon aerosols in the Los Angeles Basin during CalNex, J. Geophys. Res.-Atmos., 118, 1777-1803, 2013.

Evans, M. J. and Jacob, D. J.: Impact of new laboratory studies of $\mathrm{N}_{2} \mathrm{O}_{5}$ hydrolysis on global model budgets of tropospheric nitrogen oxides, ozone and OH, Geophys. Res. Lett., 32, L09813, https://doi.org/10.1029/2005GL022469, 2005.

Feng, Y. and Penner, J. E.: Global modeling of nitrate and ammonium: Interaction of aerosols and tropospheric chemistry, J. Geophys. Res.-Atmos., 112, D01304, https://doi.org/10.1029/2005jd006404, 2007.

Fenn, M. E., Poth, M. A., and Johnson, D. W.: Evidence for nitrogen saturation in the San Bernardino Mountains in southern California, Forest Ecol. Manag., 82, 211-230, 1996.

Fowler, Z. K., Adams, M. B., and Peterjohn, W. T.: Will more nitrogen enhance carbon storage in young forest stands in central Appalachia? Forest Ecol. Manag., 337, 144-152, 2015.

Galloway, J. N., Dentener, F. J., Capone, D. G., Boyer, E. W., Howarth, R. W., Seitzinger, S. P., Asner, G. P., Cleveland, C. C., Green, P. A., Holland, E. A., Karl, D. M., Michaels, A. F., Porter, J. H., Townsend, A. R., and Vorosmarty, C. J.: Nitrogen cycles: Past, present, and future, Biogeochemistry, 70, 153-226, 2004.

Gard, E. E., Kleeman, M. J., Gross, D. S., Hughes, L. S., Allen, J. O., Morrical, B. D., Fergenson, D. P., Dienes, T., Galli, M. E., Johnson, R. J., Cass, G. R., and Prather, K. A.: Direct observation of heterogeneous chemistry in the atmosphere, Science, 279, 1184-1187, 1998.

Hansell, D. A. and Follows, M. J.: Nitrogen in the Atlantic Ocean, chap. 13, in: Nitrogen in the Marine Environment, edited by: Mullholland, M., Bronk, D., Capone, D., and Carpenter, E., second ed., Elsevier Inc., 597-630, https://doi.org/10.1016/B978-012-372522-6.00013-X, 2008.

Hauglustaine, D. A., Hourdin, F., Walters, S., Jourdain, L., Filiberti, M.-A., Larmarque, J.-F., and Holland, E. A.: Interactive chemistry in the Laboratoire de Météorologie Dynamique general circulation model: description and background tropospheric chemistry evaluation, J. Geophys. Res., 109, D04314, https://doi.org/10.1029/2003JD003957, 2004.

Hauglustaine, D. A., Balkanski, Y., and Schulz, M.: A global model simulation of present and future nitrate aerosols and their direct radiative forcing of climate, Atmos. Chem. Phys., 14, 1103111063, https://doi.org/10.5194/acp-14-11031-2014, 2014.

Haywood, J., Bush, M., Abel, S., Claxton, B., Coe, H., Crosier, J., Harrison, M., Macpherson, B., Naylor, M., and Osborne, S.: Prediction of visibility and aerosol within the operational Met Office Unified Model II?: Validation of model performance using observational data, Q. J. Roy. Meteor. Soc., 134, 1817-1832, https://doi.org/10.1002/qj.275, 2008.

Heald, C. L., Collett Jr., J. L., Lee, T., Benedict, K. B., Schwandner, F. M., Li, Y., Clarisse, L., Hurtmans, D. R., Van Damme, M., Clerbaux, C., Coheur, P.-F., Philip, S., Martin, R. V., and Pye, H.
O. T.: Atmospheric ammonia and particulate inorganic nitrogen over the United States, Atmos. Chem. Phys., 12, 10295-10312, https://doi.org/10.5194/acp-12-10295-2012, 2012.

Hodzic, A., Vautard, R., Chazette, P., Menut, L., and Bessagnet, B.: Aerosol chemical and optical properties over the Paris area within ESQUIF project, Atmos. Chem. Phys., 6, 3257-3280, https://doi.org/10.5194/acp-6-3257-2006, 2006a.

Hodzic, A., Bessagnet, B., and Vautard, R.: A model evaluation of coarse-mode nitrate heterogeneous formation on dust particles, Atmos. Environ., 40 4158-4171, 2006 b.

Huffman, J. A., Jayne, J. T., Drewnick, F., Aiken, A. C., Onasch, T., Worsnop, D. R., and Jimenez, J. L.: Design, Modeling, Optimization, and Experimental Tests of a Particle Beam Width Probe for the Aerodyne Aerosol Mass Spectrometer, Aerosol Sci. Technol., 39, 1143-1163, 2005

Huneeus, N., Schulz, M., Balkanski, Y., Griesfeller, J., Prospero, J., Kinne, S., Bauer, S., Boucher, O., Chin, M., Dentener, F., Diehl, T., Easter, R., Fillmore, D., Ghan, S., Ginoux, P., Grini, A., Horowitz, L., Koch, D., Krol, M. C., Landing, W., Liu, X., Mahowald, N., Miller, R., Morcrette, J.-J., Myhre, G., Penner, J., Perlwitz, J., Stier, P., Takemura, T., and Zender, C. S.: Global dust model intercomparison in AeroCom phase I, Atmos. Chem. Phys., 11, 7781-7816, https://doi.org/10.5194/acp11-7781-2011, 2011.

IPCC (Intergovernmental Panel on Climate Change): The physical science basis. Contribution of working group I to the fifth assessment report of the intergovernmental panel on climate change, edited by: Stocker, T. F., Qin, D., Plattner, G.-K., Tignor, M., Allen, S. K., Boschung, J., Nauels, A., Xia, Y., Bex, V., and Midgley, P. M., Cambridge University Press, Cambridge, UK and New York, NY, USA, 2013.

Itahashi, S., Hayami, H., Uno, I., Pan, X., and Uematsu, M., Importance of coarse-mode nitrate produced via sea salt as atomspheric input to East Asian oceans, Geophys. Res. Lett., 43, 5483-5491, https://doi.org/10.1002/2016GL068722, 2016.

Jacob, D. J., Crawford, J. H., Maring, H., Clarke, A. D., Dibb, J. E., Emmons, L. K., Ferrare, R. A., Hostetler, C. A., Russell, P. B., Singh, H. B., Thompson, A. M., Shaw, G. E., McCauley, E., Pederson, J. R., and Fisher, J. A.: The Arctic Research of the Composition of the Troposphere from Aircraft and Satellites (ARCTAS) mission: design, execution, and first results, Atmos. Chem. Phys., 10, 5191-5212, https://doi.org/10.5194/acp10-5191-2010, 2010.

Jacobson, M. Z.: Global direct radiative forcing due to multicomponent anthropogenic and natural aerosols, J. Geophys. Res., 106, 1551-1568, 2001.

Janssens-Maenhout, G., Crippa, M., Guizzardi, D., Dentener, F., Muntean, M., Pouliot, G., Keating, T., Zhang, Q., Kurokawa, J., Wankmüller, R., Denier van der Gon, H., Kuenen, J. J. P., Klimont, Z., Frost, G., Darras, S., Koffi, B., and Li, M.: HTAP_v2.2: a mosaic of regional and global emission grid maps for 2008 and 2010 to study hemispheric transport of air pollution, Atmos. Chem. Phys., 15, 11411-11432, https://doi.org/10.5194/acp-15-11411-2015, 2015.

Jimenez, J. L., Canagaratna, M. R., Donahue, N. M., Prevot, A. S. H., Zhang, Q., Kroll, J. H., DeCarlo, P. F., Allan, J. D., Coe, H., Ng, N. L., Aiken, A. C., Docherty, K. S., Ulbrich, I. M., Grieshop, A. P., Robinson, A. L., Duplissy, J., Smith, J. D., Wilson, K. R., Lanz, V. A., Hueglin, C., Sun, Y. L., Tian, J., Laak- 
sonen, A., Raatikainen, T., Rautiainen, J., Vaattovaara, P., Ehn, M., Kulmala, M., Tomlinson, J. M., Collins, D. R., Cubison, M. J., Dunlea, E. J., Huffman, J. A., Onasch, T. B., Alfarra, M. R., Williams, P. I., Bower, K., Kondo, Y., Schneider, J., Drewnick, F., Borrmann, S., Weimer, S., Demerjian, K., Salcedo, D., Cottrell, L., Griffin, R., Takami, A., Miyoshi, T., Hatakeyama, S., Shimono, A., Sun, J. Y., Zhang, Y. M., Dzepina, K., Kimmel, J. R., Sueper, D., Jayne, J. T., Herndon, S. C., Trimborn, A. M., Williams, L. R., Wood, E. C., Middlebrook, A. M., Kolb, C. E., Baltensperger, U., and Worsnop, D. R.: Evolution of Organic Aerosols in the Atmosphere, Science, 326, 1525-1529, https://doi.org/10.1126/science.1180353, 2009.

Jöckel, P., Kerkweg, A., Pozzer, A., Sander, R., Tost, H., Riede, H., Baumgaertner, A., Gromov, S., and Kern, B.: Development cycle 2 of the Modular Earth Submodel System (MESSy2), Geosci. Model Dev., 3, 717-752, https://doi.org/10.5194/gmd-3717-2010, 2010.

John,W., Wall, S. M., Ondo, J. L., and Winklmayr, W.: Acidicaerosol size distributions during SCAQS (Southern California Air Quality Study), final report, Rep. CA/DOH/AIHL/SP-51, Calif. Air Resour. Board, Sacramento, USA, 1989.

Kanakidou, M., Duce, R. A., Prospero, J. M., Baker, A. R., BenitezNelson, C., Dentener, F. J., Hunter, K. A., Liss, P. S., Mahowald, N., Okin, G. S., Sarin, M., Tsigaridis, K., Uematsu, M., Zamora, L. M., and Zhu, T.: Atmospheric fluxes of organic N and $\mathrm{P}$ to the global ocean, Global Biogeochem. Cy., 26, GB3026, https://doi.org/10.1029/2011GB004277, 2012.

Kanakidou, M., Myriokefalitakis, S., Daskalakis, N., Fanourgakis, G., Nenes, A., Baker, A., Tsigaridis, K., and Mihalopoulos, N.: Past, present and future atmospheric nitrogen deposition, J. Atmos. Sci., 73, 2039-2047, https://doi.org/10.1175/JAS-D-150278.1, 2016.

Karydis, V. A., Tsimpidi, A. P., Fountoukis, C., Nenes, A., Zavala, M., Lei, W., Molina, L. T., and Pandis, S. N.: Simulating the fine and coarse inorganic particulate matter concentrations in a polluted megacity, Atmos. Environ., 44, 608-620, 2010.

Karydis, V. A., Tsimpidi, A. P., Lei, W., Molina, L. T., and Pandis, S. N.: Formation of semivolatile inorganic aerosols in the Mexico City Metropolitan Area during the MILAGRO campaign, Atmos. Chem. Phys., 11, 13305-13323, https://doi.org/10.5194/acp-1113305-2011, 2011.

Karydis, V. A., Tsimpidi, A. P., Pozzer, A., Astitha, M., and Lelieveld, J.: Effects of mineral dust on global atmospheric nitrate concentrations, Atmos. Chem. Phys., 16, 1491-1509, https://doi.org/10.5194/acp-16-1491-2016, 2016.

Kim, D., Chin, M., Yu, H., Diehl, T., Tan, Q., Kahn, R. A., Tsigaridis, K., Bauer, S. E., Takemura, T., Pozzoli, L., Bellouin, N., Schulz, M., Peyridieu, S., Chédin, A., and Koffi, B.: Sources, sinks, and transatlantic transport of North African dust aerosol: A multi-model analysis and comparison with remote-sensing data, J. Geophys. Res. Atmos., 119, 6259-6277, https://doi.org/10.1002/2013JD021099, 2014.

Kim, Y. P., Seinfeld, J. H., and Saxena, P.: Atmospheric gas-aerosol equilibrium I. Thermodynamic model, Aerosol Sci. Technol., 19, 157-181, 1993.

Kinne, S., Schulz, M., Textor, C., Guibert, S., Balkanski, Y., Bauer, S. E., Berntsen, T., Berglen, T. F., Boucher, O., Chin, M., Collins, W., Dentener, F., Diehl, T., Easter, R., Feichter, J., Fillmore, D., Ghan, S., Ginoux, P., Gong, S., Grini, A., Hendricks, J., Herzog,
M., Horowitz, L., Isaksen, I., Iversen, T., Kirkevåg, A., Kloster, S., Koch, D., Kristjansson, J. E., Krol, M., Lauer, A., Lamarque, J. F., Lesins, G., Liu, X., Lohmann, U., Montanaro, V., Myhre, G., Penner, J., Pitari, G., Reddy, S., Seland, O., Stier, P., Takemura, T., and Tie, X.: An AeroCom initial assessment - optical properties in aerosol component modules of global models, Atmos. Chem. Phys., 6, 1815-1834, https://doi.org/10.5194/acp-61815-2006, 2006.

Koch, D., Schulz, M., Kinne, S., McNaughton, C., Spackman, J. R., Balkanski, Y., Bauer, S., Berntsen, T., Bond, T. C., Boucher, O., Chin, M., Clarke, A., De Luca, N., Dentener, F., Diehl, T., Dubovik, O., Easter, R., Fahey, D. W., Feichter, J., Fillmore, D., Freitag, S., Ghan, S., Ginoux, P., Gong, S., Horowitz, L., Iversen, T., Kirkevåg, A., Klimont, Z., Kondo, Y., Krol, M., Liu, X., Miller, R., Montanaro, V., Moteki, N., Myhre, G., Penner, J. E., Perlwitz, J., Pitari, G., Reddy, S., Sahu, L., Sakamoto, H., Schuster, G., Schwarz, J. P., Seland, Ø., Stier, P., Takegawa, N., Takemura, T., Textor, C., van Aardenne, J. A., and Zhao, Y.: Evaluation of black carbon estimations in global aerosol models, Atmos. Chem. Phys., 9, 9001-9026, https://doi.org/10.5194/acp-99001-2009, 2009.

Lamarque, J.-F., Kiehl, J. T., Brasseur, G. P., Butler, T., CameronSmith, P., Collins, W., Collins, W., Granier, C., Hauglustaine, D., and Hess, P.: Assessing future nitrogen deposition and carbon cycle feedback using a multimodel approach : Analysis of nitrogen deposition, J. Geophys. Res., 110, D19303, https://doi.org/10.1029/2005JD005825, 2005.

Lee, T., Yu, X.-Y., Ayres, B., Kreidenweis, S. M., Malm, W. C., and Collett Jr., J. L.: Observations of fine and coarse particle nitrate at several rural locations in the United States, Atmos. Environ., 42, 2720-2732, 2008.

Lefer, B. L. and Talbot, R. W.: Summertime measurements of aerosol nitrate and ammonium at a northeastern US site, J. Geophys. Res., 106, 20365-20378, 2001.

Li, J., Wang, W.-C., Liao, H., and Chang, W.: Past and future direct radiative forcing of nitrate aerosol in East Asia, Theor. Appl. Climatol., 121, 445-458, https://doi.org/10.1007/s00704-014-1249$1,2014$.

Liao, H., Adams, P. J., Chung, S. H., Seinfeld, J. H., Mickley, L. J., and Jacob, D. J.: Interactions between tropospheric chemistry and aerosols in a unified general circulation model, J. Geophys. Res., 108, 4001, https://doi.org/10.1029/2001JD001260, 2003.

Malm, W. C., Schichtel, B. A., Pitchford, M. L., Ashbaugh, L. L., and Eldred, R. A.: Spatial and monthly trends in speciated fine particle concentration in the United States, J. Geophys. Res.Atmos., 109, D03306, https://doi.org/10.1029/2003JD003739, 2004.

Meng, Z. Y. and Seinfeld, J. H.: Time scales to achieve atmospheric gas-aerosol equilibrium for volatile species, Atmos. Environ., 30, 2889-2900, https://doi.org/10.1016/1352-2310(95)00493-9, 1996.

Metzger, S., Dentener, F., Pandis, S., and Lelieveld, J.: Gas/aerosol partitioning: 1. A computationally efficient model, J. Geophys. Res., 107, D164312, https://doi.org/10.1029/2001JD001102, 2002.

Mezuman, K., Bauer, S. E., and Tsigaridis, K.: Evaluating secondary inorganic aerosols in three dimensions, Atmos. Chem. Phys., 16, 10651-10669, https://doi.org/10.5194/acp-16-106512016, 2016. 
Murphy, D. M. and Thomson, D. S.: Chemical composition of single aerosol particles at Idaho Hill: Negative ion measurements, J. Geophys. Res., 102, 6353-6368, 1997.

Myhre, G., Grini, A., and Metzger, S.: Modelling of nitrate and ammonium-containing aerosols in presence of sea salt, Atmos. Chem. Phys., 6, 4809-4821, https://doi.org/10.5194/acp-6-48092006, 2006.

Myhre, G., Samset, B. H., Schulz, M., Balkanski, Y., Bauer, S., Berntsen, T. K., Bian, H., Bellouin, N., Chin, M., Diehl, T., Easter, R. C., Feichter, J., Ghan, S. J., Hauglustaine, D., Iversen, T., Kinne, S., Kirkevåg, A., Lamarque, J.-F., Lin, G., Liu, X., Lund, M. T., Luo, G., Ma, X., van Noije, T., Penner, J. E., Rasch, P. J., Ruiz, A., Seland, Ø., Skeie, R. B., Stier, P., Takemura, T., Tsigaridis, K., Wang, P., Wang, Z., Xu, L., Yu, H., Yu, F., Yoon, J.-H., Zhang, K., Zhang, H., and Zhou, C.: Radiative forcing of the direct aerosol effect from AeroCom Phase II simulations, Atmos. Chem. Phys., 13, 1853-1877, https://doi.org/10.5194/acp13-1853-2013, 2013.

Paulot, F., Ginoux, P., Cooke, W. F., Donner, L. J., Fan, S., Lin, M.-Y., Mao, J., Naik, V., and Horowitz, L. W.: Sensitivity of nitrate aerosols to ammonia emissions and to nitrate chemistry: implications for present and future nitrate optical depth, Atmos. Chem. Phys., 16, 1459-1477, https://doi.org/10.5194/acp16-1459-2016, 2016.

Phoenix, G., Hicks, W. K., Cinderby, S., Kuylenstierna, J. C. I., Stock, W. D., Dentener, F. J., Giller, K. E., Austin, A. T., Lefroy, R. D. B., Gimeno, B. S., Ashmore, M. R., and Ineson, P.: Atmospheric nitrogen deposition in world biodiversity hotspots: the need for a greater global perspective in assessing $\mathrm{N}$ deposition impacts, Glob. Change Biol., 12, 470-476, https://doi.org/10.1111/j.1365-2486.2006.01104.x, 2006.

Prentice, M. J., Farquhar, G. D., Fasham, M. J. R., Goulden, M. L., Heimann, M., Jaramillo, V. J., Kheshgi, H. S., Le Quéré, C., Scholes, R. J., and Wallace, D. W. R.: The carbon cycle and atmospheric carbon dioxide, in: Climate Change 2001, 184-237, Cambridge Univ. Press, New York, USA, 2001.

Pringle, K. J., Tost, H., Message, S., Steil, B., Giannadaki, D., Nenes, A., Fountoukis, C., Stier, P., Vignati, E., and Lelieveld, J.: Description and evaluation of GMXe: a new aerosol submodel for global simulations (v1), Geosci. Model Dev., 3, 391-412, https://doi.org/10.5194/gmd-3-391-2010, 2010.

Pusede, S. E., Duffey, K. C., Shusterman, A. A., Saleh, A., Laughner, J. L., Wooldridge, P. J., Zhang, Q., Parworth, C. L., Kim, H., Capps, S. L., Valin, L. C., Cappa, C. D., Fried, A., Walega, J., Nowak, J. B., Weinheimer, A. J., Hoff, R. M., Berkoff, T. A., Beyersdorf, A. J., Olson, J., Crawford, J. H., and Cohen, R. C.: On the effectiveness of nitrogen oxide reductions as a control over ammonium nitrate aerosol, Atmos. Chem. Phys., 16, 25752596, https://doi.org/10.5194/acp-16-2575-2016, 2016.

Riemer, N., Vogel, H., Vogel, B., Schell, B., Ackermann, I., Kessler, C., and Hass, H.: Impact of the heterogeneous hydrolysis of $\mathrm{N}_{2} \mathrm{O}_{5}$ on chemistry and nitrate aerosol formation in the lower troposphere under photosmog conditions, J. Geophys. Res., 108, 4144, https://doi.org/10.1029/2002JD002436, 2003.

Sadanaga, Y., Shibata, S., Hamana, M., Takenaka, N., and Bandow, H.: Weekday/Weekend difference of ozone and its precursors in urban areas of Japan, focusing on ni trogen oxides and hydrocarbons, Atmos. Environ., 42, 4708-4723, 2008.
Schaap, M., Müller, K., and Ten Brink, H. M.: Constructing the European aerosol nitrate concentration field from quality analysed data, Atmos. Environ., 36, 1323-1335, 2002.

Schaap, M., van Loon, M., ten Brink, H. M., Dentener, F. J., and Builtjes, P. J. H.: Secondary inorganic aerosol simulations for Europe with special attention to nitrate, Atmos. Chem. Phys., 4, 857-874, https://doi.org/10.5194/acp-4-857-2004, 2004.

Schmidt, G. A., Kelley, M., Nazarenko, L., Ruedy, R., Russell, G. L., Aleinov, I., Bauer, M., Bauer, S. E., Bhat, M. K., Bleck, R., Canuto, V., Chen, Y.-H., Cheng, Y., Clune, T. L., Del Genio, A., de Fainchtein, R., Faluvegi, G., Hansen, J. E., Healy, R. J., Kiang, N. Y., Koch, D., Lacis, A. A., LeGrande, A. N., Lerner, J., Lo, K. K., Matthews, E. E., Menon, S., Miller, R. L., Oinas, V., Oloso, A. O., Perlwitz, J. P., Puma, M. J., Putman, W. M., Rind, D., Romanou, A., Sato, M., Shindell, D. T., Sun, S., Syed, R. A., Tausnev, N., Tsigaridis, K., Unger, N., Voulgarakis, A., Yao, M.-S., and Zhang, J.: Configuration and assessment of the GISS ModelE2 contributions to the CMIP5 archive, J. Adv. Model. Earth Syst., 6, 141-184, https://doi.org/10.1002/2013MS000265, 2014.

Schulz, M., Textor, C., Kinne, S., Balkanski, Y., Bauer, S., Berntsen, T., Berglen, T., Boucher, O., Dentener, F., Guibert, S., Isaksen, I. S. A., Iversen, T., Koch, D., Kirkevåg, A., Liu, X., Montanaro, V., Myhre, G., Penner, J. E., Pitari, G., Reddy, S., Seland, Ø., Stier, P., and Takemura, T.: Radiative forcing by aerosols as derived from the AeroCom present-day and pre-industrial simulations, Atmos. Chem. Phys., 6, 5225-5246, https://doi.org/10.5194/acp6-5225-2006, 2006.

Schutgens, N. A. J., Gryspeerdt, E., Weigum, N., Tsyro, S., Goto, D., Schulz, M., and Stier, P.: Will a perfect model agree with perfect observations? The impact of spatial sampling, Atmos. Chem. Phys., 16, 6335-6353, https://doi.org/10.5194/acp-166335-2016, 2016.

Shindell, D. T., Faluvegi, G., and Bell, N.: Preindustrial-to-presentday radiative forcing by tropospheric ozone from improved simulations with the GISS chemistry-climate GCM, Atmos. Chem. Phys., 3, 1675-1702, https://doi.org/10.5194/acp-3-1675-2003, 2003.

Shindell, D. T., Chin, M., Dentener, F., Doherty, R. M., Faluvegi, G., Fiore, A. M., Hess, P., Koch, D. M., MacKenzie, I. A., Sanderson, M. G., Schultz, M. G., Schulz, M., Stevenson, D. S., Teich, H., Textor, C., Wild, O., Bergmann, D. J., Bey, I., Bian, H., Cuvelier, C., Duncan, B. N., Folberth, G., Horowitz, L. W., Jonson, J., Kaminski, J. W., Marmer, E., Park, R., Pringle, K. J., Schroeder, S., Szopa, S., Takemura, T., Zeng, G., Keating, T. J., and Zuber, A.: A multi-model assessment of pollution transport to the Arctic, Atmos. Chem. Phys., 8, 5353-5372, https://doi.org/10.5194/acp-8-5353-2008, 2008.

Silvern, R. F., Jacob, D. J., Kim, P. S., Marais, E. A., Turner, J. R., Campuzano-Jost, P., and Jimenez, J. L.: Inconsistency of ammonium-sulfate aerosol ratios with thermodynamic models in the eastern US: a possible role of organic aerosol, Atmos. Chem. Phys., 17, 5107-5118, https://doi.org/10.5194/acp17-5107-2017, 2017.

Simpson, D., Benedictow, A., Berge, H., Bergström, R., Emberson, L. D., Fagerli, H., Flechard, C. R., Hayman, G. D., Gauss, M., Jonson, J. E., Jenkin, M. E., Nyíri, A., Richter, C., Semeena, V. S., Tsyro, S., Tuovinen, J.-P., Valdebenito, Á., and Wind, P.: The EMEP MSC-W chemical transport model 
- technical description, Atmos. Chem. Phys., 12, 7825-7865, https://doi.org/10.5194/acp-12-7825-2012, 2012.

Søvde, O. A., Prather, M. J., Isaksen, I. S. A., Berntsen, T. K., Stordal, F., Zhu, X., Holmes, C. D., and Hsu, J.: The chemical transport model Oslo CTM3, Geosci. Model Dev., 5, 1441-1469, https://doi.org/10.5194/gmd-5-1441-2012, 2012.

Strahan, S. E., Duncan, B. N., and Hoor, P.: Observationally derived transport diagnostics for the lowermost stratosphere and their application to the GMI chemistry and transport model, Atmos. Chem. Phys., 7, 2435-2445, https://doi.org/10.5194/acp-72435-2007, 2007.

Sudo, K., Takahashi, M., Kurokawa, J., and Akimoto, H.: CHASER: A global chemical model of the troposphere, 1. Model description, J. Geophys. Res., 107, 4339, https://doi.org/10.1029/2001JD001113, 2002.

Textor, C., Schulz, M., Guibert, S., Kinne, S., Balkanski, Y., Bauer, S., Berntsen, T., Berglen, T., Boucher, O., Chin, M., Dentener, F., Diehl, T., Easter, R., Feichter, H., Fillmore, D., Ghan, S., Ginoux, P., Gong, S., Grini, A., Hendricks, J., Horowitz, L., Huang, P., Isaksen, I., Iversen, I., Kloster, S., Koch, D., Kirkevåg, A., Kristjansson, J. E., Krol, M., Lauer, A., Lamarque, J. F., Liu, X., Montanaro, V., Myhre, G., Penner, J., Pitari, G., Reddy, S., Seland, Ø., Stier, P., Takemura, T., and Tie, X.: Analysis and quantification of the diversities of aerosol life cycles within AeroCom, Atmos. Chem. Phys., 6, 1777-1813, https://doi.org/10.5194/acp-6-17772006, 2006.

Tost, H., Jöckel, P., Kerkweg, A., Sander, R., and Lelieveld, J.: Technical note: A new comprehensive SCAVenging submodel for global atmospheric chemistry modelling, Atmos. Chem. Phys., 6, 565-574, https://doi.org/10.5194/acp-6-565-2006, 2006.

Trail, M., Tsimpidi, A. P., Liu, P., Tsigaridis, K., Rudokas, J., Miller, P., Nenes, A., Hu, Y., and Russell, A. G.: Sensitivity of air quality to potential future climate change and emissions in the United States and major cities, Atmos. Environ., 94, 552-563, 2014.

Trump, E. R., Fountoukis, C., Donahue, N. M., and Pandis, S. N.: Improvement of simulation of fine inorganic PM levels through better descriptions of coarse particle chemistry, Atmos. Environ., 102, 274-281, 2015.

Tsigaridis, K., Daskalakis, N., Kanakidou, M., Adams, P. J., Artaxo, P., Bahadur, R., Balkanski, Y., Bauer, S. E., Bellouin, N., Benedetti, A., Bergman, T., Berntsen, T. K., Beukes, J. P., Bian, H., Carslaw, K. S., Chin, M., Curci, G., Diehl, T., Easter, R. C., Ghan, S. J., Gong, S. L., Hodzic, A., Hoyle, C. R., Iversen, T., Jathar, S., Jimenez, J. L., Kaiser, J. W., Kirkevåg, A., Koch, D., Kokkola, H., Lee, Y. H., Lin, G., Liu, X., Luo, G., Ma, X., Mann, G. W., Mihalopoulos, N., Morcrette, J.-J., Müller, J.-F., Myhre, G., Myriokefalitakis, S., Ng, N. L., O'Donnell, D., Penner, J. E., Pozzoli, L., Pringle, K. J., Russell, L. M., Schulz, M., Sciare, J., Seland, Ø., Shindell, D. T., Sillman, S., Skeie, R. B., Spracklen, D., Stavrakou, T., Steenrod, S. D., Takemura, T., Tiitta, P., Tilmes, S., Tost, H., van Noije, T., van Zyl, P. G., von Salzen, K., Yu, F., Wang, Z., Wang, Z., Zaveri, R. A., Zhang, H., Zhang, K., Zhang, Q., and Zhang, X.: The AeroCom evaluation and intercomparison of organic aerosol in global models, Atmos. Chem. Phys., 14, 10845-10895, https://doi.org/10.5194/acp-1410845-2014, 2014
Tsimpidi, A. P., Karydis, V. A., and Pandis, S. N.: Response of inorganic fine particulate matter to emission changes of sulfur dioxide and ammonia: The eastern United States as a case study, J. Air Waste Manage., 57, 1489-1498, 2007.

Tsimpidi, A. P., Karydis, V. A., and Pandis, S. N.: Response of Fine Particulate Matter to Emission Changes of Oxides of Nitrogen and-Anthropogenic Volatile Organic Compounds in the Eastern United States, J. Air Waste Manage., 58, 1463-1473, 2008.

van der Werf, G. R., Randerson, J. T., Giglio, L., Collatz, G. J., Mu, M., Kasibhatla, P. S., Morton, D. C., DeFries, R. S., Jin, Y., and van Leeuwen, T. T.: Global fire emissions and the contribution of deforestation, savanna, forest, agricultural, and peat fires (1997-2009), Atmos. Chem. Phys., 10, 11707-11735, https://doi.org/10.5194/acp-10-11707-2010, 2010.

Van Milegroet, H. and Cole, D. W.: The Impact of Nitrification on Soil Acidification and Cation Leaching in a Red Alder Ecosystem, ACSESS, Alliance of Crop, Soil, and Environmental Science Societies, J. Environ. Qual., 13, 586590, https://doi.org/10.2134/jeq1984.00472425001300040015x, 1984.

Vieno, M., Heal, M. R., Twigg, M. M., MacKenzie, I. A., Braban, C. F., Lingard, J. J. N. Ritchie, S., Beck, R. C., A., M., Ots, R., DiMarco, C. F., Nemitz, E., Sutton, M. A., and Reis, S.: The UK particulate matter air pollution episode of March-April 2014: more than Saharan dust, Environ. Res. Lett., 11044004 , https://doi.org/10.1088/1748-9326/11/4/044004, 2016.

Walker, J. M., Philip, S., Martin, R. V., and Seinfeld, J. H.: Simulation of nitrate, sulfate, and ammonium aerosols over the United States, Atmos. Chem. Phys., 12, 11213-11227, https://doi.org/10.5194/acp-12-11213-2012, 2012.

Watanabe, S., Hajima, T., Sudo, K., Nagashima, T., Takemura, T., Okajima, H., Nozawa, T., Kawase, H., Abe, M., Yokohata, T., Ise, T., Sato, H., Kato, E., Takata, K., Emori, S., and Kawamiya, M.: MIROC-ESM 2010: model description and basic results of CMIP5-20c3m experiments, Geosci. Model Dev., 4, 845-872, https://doi.org/10.5194/gmd-4-845-2011, 2011.

Weber, R. J., Guo, H., Russell, A. G., and Nenes, A.: High aerosol acidity despite declining atmospheric sulfate concentrations over the past 15 years, Nature Geosci., 9, 282-285, https://doi.org/10.1038/ngeo2665, 2016.

Williams, E. J., Sandholm, S. T., Bradshaw, J. D., Schendel, J. S., Langford, A. O., Quinn, P. K., LeBel, P. J., Vay, S. A., Roberts, P. D., Norton, R. B., Watkins, B. A., Buhr, M. P., Parrish, D. D., Calvert, J. G., and Fehsenfeld, F. C.: An intercomparison of five ammonia measurement techniques, J. Geophys. Res., 97, 11591$11611,1992$.

$\mathrm{Xu}$, L. and Penner, J. E.: Global simulations of nitrate and ammonium aerosols and their radiative effects, Atmos. Chem. Phys., 12, 9479-9504, https://doi.org/10.5194/acp-12-94792012, 2012.

Yeatman, S. G., Spokes, L. J., Dennis, P. F., and Jickells, T. D.: Comparisons of aerosol nitrogen isotopic composition at two polluted coastal sites, Atmos. Environ. 35, 1307-1320, 2001.

Zhou, J., Gu, B., Schlesinger, W. H., and Ju, X.: Significant accumulation of nitrate in Chinese semi-humid croplands, Sci. Rep., 6, 25088, https://doi.org/10.1038/srep25088, 2016. 